\title{
Behaviour of Sand-filled Plastic Bottled Clay Panels for Sustainable Homes
}

\author{
Boksun Kim ${ }^{\mathrm{a},{ }^{*}}$, Josef Wisniewski ${ }^{\mathrm{a}}$, Toby Baker ${ }^{\mathrm{a}}$ and Muyiwa Oyinlola ${ }^{\mathrm{b}}$ \\ a School of Engineering, the University of Plymouth, Plymouth, PL4 8AA, UK \\ *boksun.kim@plymouth.ac.uk \\ ${ }^{b}$ School of Engineering and Sustainable Development, De Montfort University, Leicester, \\ LE1 9BH, UK
}

\begin{abstract}
Adequate shelter is a basic necessity for human existence and mankind has continuously improved the quality of shelter. It is estimated that about 1.6 billion people still lack adequate housing. There is a cogent need for developing new methods of delivering housing that can be accessible to low-income communities who have little or no access to finances. Plastic bottles have been suggested as a candidate material for constructing low-cost, environmentally friendly homes in developing countries. Although some research on the use of plastic bottles for housing was found, the existing literature shows considerable discrepancies in the strength of plastic bottles and bottled cubes. Furthermore, the literature is limited to cement cubes and no research has been carried out using locally sustainable materials such as soils. As part of the 'Bottle House' project for developing low-cost sustainable homes in Nigeria, this paper seeks to fill this gap by reporting the results of two series of experimental work carried out at the University of Plymouth. A total of eight-four $500 \mathrm{ml}$ PET bottles and twelve wall and floor panels with and without sand-filled plastic bottles were prepared and tested to investigate their strength and failure behaviour. The test results have shown that in-filled sands made a significant contribution to the strength of the bottles and the bottles tested vertically resisted better than those tested horizontally. They have also shown that the panels with sand-filled bottles have about a quarter of the strength of the daub only panels due to a lack of cohesion between bottles and daub, but they are found to be more ductile than the latter.
\end{abstract}

Keywords: sand-filled PET bottles; plastic bottled clay panels; sustainable homes; lowcost affordable housing; plastic bottle compressive testing; bottled panel testing; failure modes; bottle house 


\section{Introduction}

Adequate shelter is a basic necessity for human existence and mankind has continuously improved the quality of shelter. The right to adequate housing is embedded in the Universal Declaration of Human Rights (1948). Despite the fact that, over the last century, several affordable and low-cost housing initiatives have been rolled out, it is estimated that about 1.6 billion people still lack adequate housing (Habitat, 2017). This indicates that the term, 'affordable' is relative and usually does not include the very low-income communities. It therefore means that there is a cogent need for developing new methods of delivering housing that can be accessible to low-income communities who have little or no access to finances.

One way of transforming the way housing can be delivered is the flexibility in the type of material used as well as level of skilled labour required. Over the last few decades, several new methods of delivering housing have emerged, such as pre-fabricated homes, timber frame construction etc. However, most of these are not suitable for low-income communities in developing countries. The concept used by most rural and low-income communities is making use of materials available, which significantly reduces costs (Morel et al. 2001). For example, in Nigeria, the focus of this study, using clay bricks and thatch roofs is a common method of building in rural areas, however this method suffers from environmental conditions such as rain causing the blocks to deteriorate.

Construction materials make up a high percentage of construction costs since the cost of labour in low income communities, is relatively cheap, Also, the infrastructure for waste management in low income communities is poor or non-existent. Therefore, using plastic bottles will not only lower construction cost by replacing traditional materials but can also place a higher premium on these wastes which can strengthen the informal waste management system. Several researchers such as (Mansour \& Ali, 2015; Mokhtar et al., 2016; Muyen et al., 2016; Rawat \& Kansal, 2014; Oyinlola et al., 2018) have suggested plastic bottles as a candidate material for constructing low cost, environmentally-friendly homes.

Figure 1 shows an example of such a house built in Abuja, Nigeria. The use of plastic bottles as a building component has several advantages. For example, since plastic bottles are non-brittle, construction waste will be greatly reduced compared with using conventional blocks. This also implies they can be reused if a wall is destroyed. Similarly, if maintained properly, plastics have a life expectancy of up to 300 years. Using waste plastic bottle for building walls can increase the levels of affordable housings available to the low and middleincome groups of developing countries. The use of waste plastic bottles in this way also has implication for the environment as it can reduce the number of plastic bottles, which go to waste every year. 

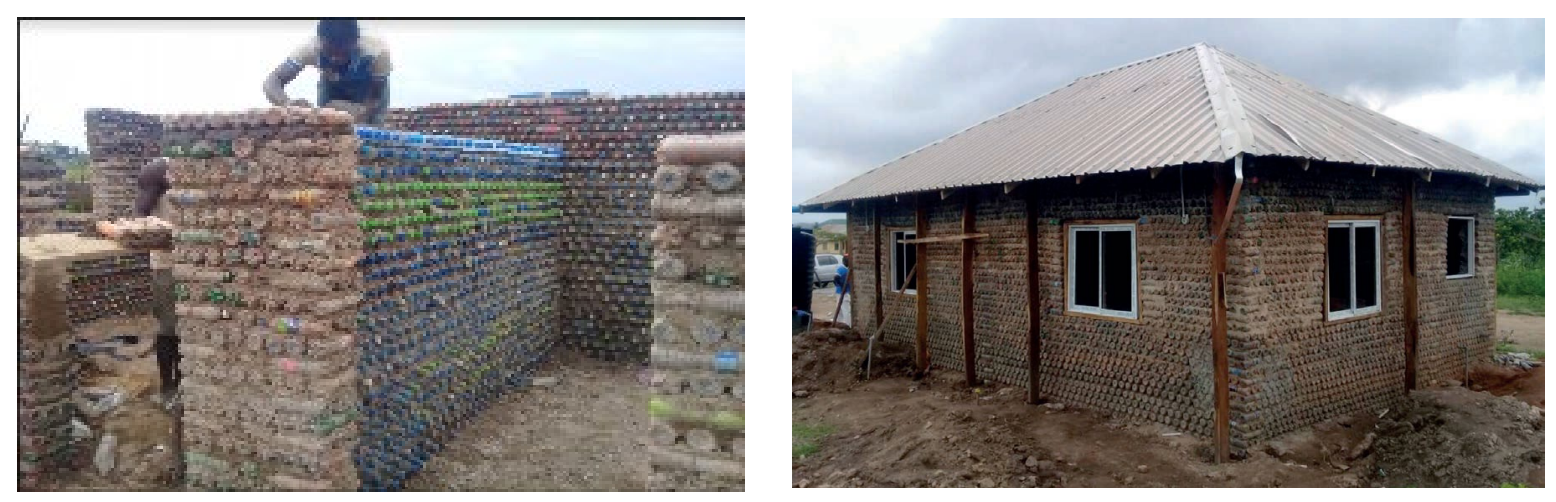

Figure 1 Bottle house in Paipe, Abuja, Nigeria (Oyinlola et al., 2018)

The compressive strength of a plastic bottle, filled with waste plastic bags (Taaffe et al. 2014), soil (Rawat and Kansal, 2014) or sands (Muyen et al., 2016; Mokhtar et al., 2016) was investigated. The bottles were tested lying down, which is the same way they would be placed in a wall. Table 1 compares the compressive strength of such plastic bottles. Eight $500 \mathrm{ml}$ bottles filled with waste plastic bags gave an average strength of $2.72 \mathrm{~N} / \mathrm{mm}^{2}$ (Taaffe et al., 2014), while eight $600 \mathrm{ml}$ soil filled bottles are found to have an average of $8.99 \mathrm{~N} / \mathrm{mm}^{2}$ (Rawat and Kansal, 2014). Plastic bottles filled with sands are found to have the highest compressive strength since the work by Muyen et al. (2016) showed that the sand filled bottles ranging from $250 \mathrm{ml}$ to 2 litres gave the strength up to $17.44 \mathrm{~N} / \mathrm{mm}^{2}$. The bigger capacity of a bottle, the higher compressive strength. The work by Mokhtar et al. (2016) showed even higher compressive strength. Their tests using $250 \mathrm{ml}$ and 1.5 litre bottles, filled with partially wet sands gave a value of $38.34 \mathrm{~N} / \mathrm{mm}^{2}$ and $27.39 \mathrm{~N} / \mathrm{mm}^{2}$ respectively. The $250 \mathrm{ml}$ bottles gave about 1.4 times higher strength than that of the 1.5 litre ones. This contradicts the findings by Muyen et al. (2016). Furthermore, the areas used for the calculation of the strength seem to be significantly smaller than those found in the work by Taaffe, et al. (2014) and Rawat and Kansal (2014), as shown in Table 1. The contact area of the 1.5 litre bottle is less than a half of the $500 \mathrm{ml}$. This seems well underestimated. However, Mokhtar, et al. (2016) did not specify how the areas were obtained.

Table 1 Research on the compressive strength of a plastic bottle

\begin{tabular}{|l|c|c|c|c|}
\hline \multicolumn{1}{|c|}{ Researchers } & $\begin{array}{c}\text { Bottle } \\
\text { capacity }\end{array}$ & Filling & $\begin{array}{c}\text { Area used for the } \\
\text { calculation of compressive } \\
\text { strength }\left(\mathrm{mm}^{2}\right)\end{array}$ & $\begin{array}{c}\text { Compressive } \\
\text { strength } \\
\text { (N/mm }\end{array}$ \\
\hline Muyen, et al. (2016) & $\begin{array}{c}250 \mathrm{ml} \text { to } \\
2 \text { litre }\end{array}$ & Sands & Not provided. & 8 to 17.44 \\
\hline Mokhtar, et al. (2016) & $250 \mathrm{ml}$ & Sands & 2000 & 38.34 \\
\cline { 2 - 5 } & 1.5 litre & Sands & 6000 & 27.39 \\
\hline Taaffe, et al. (2014) & $500 \mathrm{ml}$ & Plastic bags & 13600 & 2.55 to 2.9 \\
\hline Rawat and Kansal (2014) & $600 \mathrm{ml}$ & soil & 14200 & 8.99 \\
\hline
\end{tabular}

The tests on cement mortar cylinders of $150 \mathrm{~mm}$ diameter and $300 \mathrm{~mm}$ long, embedding a 1.0 litre sand filled plastic bottle were conducted by Muyen et al. (2016). They found that the compressive and tensile strengths of such cylinders were $19.9 \mathrm{~N} / \mathrm{mm}^{2}$ and $1.7 \mathrm{~N} / \mathrm{mm}^{2}$ respectively at 28 days after casting.

The compressive strength of cement cubes incorporating air (Masour and Ali, 2015), soil (Revathi et al., 2017; Patel, et al., 2016) or sands (Muyen et al., 2016; Masour and Ali, 2015) 
filled plastic bottles were investigated. Table 2 compares the strength of such cubes. 8 to 12 bottles were placed in three layers. The values of the strengths ranged from 0.61 to 35 $\mathrm{N} / \mathrm{mm}^{2}$ as shown in Table 2. The strength of the cubes by Muyen et al (2016) is approximately 57 times higher than that by Masour and Ali (2015).

The considerable discrepancies in the compressive strength of both plastic bottles and cement cubes incorporating plastic bottles, as shown in Tables 1 and 2, cast some doubt in the validity of the test results and may hinder the use of plastic bottles for construction. Hence, more research is needed to clarify the discrepancies. Furthermore, the literature is limited to cement cubes and no research has been carried out using locally sustainable materials such as soils. Therefore, it is impossible to predict the mechanics of failure in this type of construction. As this type of structures are usually in low income communities, with low level of skills available, an ability to predict and mitigate the mechanics of failure is extremely important. As part of the bottle house project for developing low-cost sustainable homes in Nigeria (Oyinlola et al., 2018), this paper seeks to fill this gap by reporting the results of experimental work carried out at the University of Plymouth to characterise empty and sand filled plastic bottles, and to investigate the structural suitability of sand filled plastic bottled clay panels as building materials.

This study is especially important as there has been a significant increase in the use of plastic bottles for constructions in low and middle income countries such as Nigeria, India, Bangladesh, and Panama (Oyinlola and Whitehead 2019). Media reports have claimed that in addition to tackling the plastic waste challenge, these houses have several advantages including strength and durability. The result of this study illustrates that failure modes in this context differs from conventional construction. This paper further provides insights into the failure modes and discusses how the performance can be improved. The study also has implications for governments and NGOs who intend to adopt this method of construction for building low cost homes or housing for internally displaced people.

Table 2 Compressive strength of cement cubes incorporating plastic bottles at 28 days

\begin{tabular}{|l|c|c|c|c|c|c|}
\hline \multicolumn{1}{|c|}{ Researchers } & $\begin{array}{c}\text { Cube } \\
\text { size }\end{array}$ & $\begin{array}{c}\text { Bottle } \\
\text { capacity }\end{array}$ & Filling & $\begin{array}{c}\text { Cement: } \\
\text { Sands: } \\
\text { Water }\end{array}$ & $\begin{array}{c}\text { Number of } \\
\text { bottles }\end{array}$ & $\begin{array}{c}\text { Compressive } \\
\text { strength } \\
\left(\mathrm{N} / \mathrm{mm}^{2}\right)\end{array}$ \\
\hline Revathi et al. (2017) & $300 \mathrm{~mm}$ & $\mathrm{NS}^{*}$ & Soil & $\mathrm{NS}^{*}$ & $\mathrm{NS}^{*}$ & 2.56 \\
\hline Patel et al. (2016) & $300 \mathrm{~mm}$ & $\mathrm{NS}^{*}$ & Soil & $1: 3: \mathrm{NS}$ & $\mathrm{NS}^{*}$ & 2.7 \\
\hline Muyen et al. (2016) & $254 \mathrm{~mm}$ & $500 \mathrm{ml}$ & Sands & $1: 3: 0.6$ & 9 & 35.0 \\
\cline { 5 - 7 } & & & & 12 & 33.7 \\
\hline Mansour and Ali (2015) & $300 \mathrm{~mm}$ & 1.5 litre & Sands; air & $1: 2: 0.54$ & 8 & $0.61 ; 0.67$ \\
\hline
\end{tabular}

${ }^{*} \mathrm{NS}$ denotes not specified.

\section{Experimental Work}

A series of tests were conducted at the Materials, Heavy Structures and Materials Characterisation Laboratories at the University of Plymouth to investigate the strength and failure behaviour of plastic bottles and sand-filled plastic bottled clay panels. The following sections describe the tests carried out.

\subsection{Tests of $500 \mathrm{ml}$ Polyethylene Terephthalate (PET) bottles}


A total of eight-four $500 \mathrm{ml} \mathrm{PET} \mathrm{bottles} \mathrm{were} \mathrm{prepared} \mathrm{and} \mathrm{tested.} \mathrm{Table} 3$ shows the arrangements of the specimens. Eight sets of tests were prepared. Each set had three identical specimens. Four sets had empty bottles and the other four filled with dry sands. Four sets had single bottles and the other four sets a row of six bottles, tied using a string. The latter was to determine the characteristics of the bottles as a group. Figure 2 shows the dimensions of a single bottle. A single empty bottle weighed an average of $25 \mathrm{gram}$ and about 855 gram when filled with fine dry sands. The thickness of the plastic bottle was 0.5 $\mathrm{mm}$.

Table 3 Test arrangements of the $500 \mathrm{ml}$ PET bottles

\begin{tabular}{|c|c|c|c|c|}
\hline $\begin{array}{c}\text { Specimen } \\
\text { group }\end{array}$ & $\begin{array}{c}\text { Number of } \\
\text { bottles }\end{array}$ & $\begin{array}{c}\text { Loading } \\
\text { direction }\end{array}$ & $\begin{array}{c}\text { Empty I } \\
\text { Sand -filled }\end{array}$ & $\begin{array}{c}\text { Mass } \\
(\mathbf{k g})\end{array}$ \\
\hline A & Single & Vertical & Empty & 0.025 \\
\hline B & Single & Horizontal & Empty & 0.025 \\
\hline C & Single & Vertical & Sand-filled & 0.855 \\
\hline D & Single & Horizontal & Sand-filled & 0.855 \\
\hline E & Row of six & Vertical & Empty & 0.160 \\
\hline F & Row of six & Horizontal & Empty & 0.160 \\
\hline G & Row of six & Vertical & Sand-filled & 5.408 \\
\hline H & Row of six & Horizontal & Sand-filled & 5.408 \\
\hline
\end{tabular}

Four sets were tested vertically and the other four sets horizontally, i.e. bottles laid down. Tables of 4 and 5 show snapshots of the tests of a single and a row of six 500 ml PET bottles respectively. An Instron 5582 Universal Testing Machine was used to apply loading via a displacement control of $20 \mathrm{~mm}$ per minute. A stainless-steel plate with a diameter of $140 \mathrm{~mm}$ and thickness of $15 \mathrm{~mm}$ was placed on top of the singular bottles and an aluminium plate of $280 \mathrm{~mm}$ wide, $500 \mathrm{~mm}$ long and $10 \mathrm{~mm}$ thick was used for the row of six empty bottles to ensure that an equal load was applied to the whole specimen. Prior to each test, the machine was calibrated to ensure the plate was distributing an equal load on to the bottles. None of the bottles was airtight. Yield and ultimate loads and displacements at the yield loads were measured.
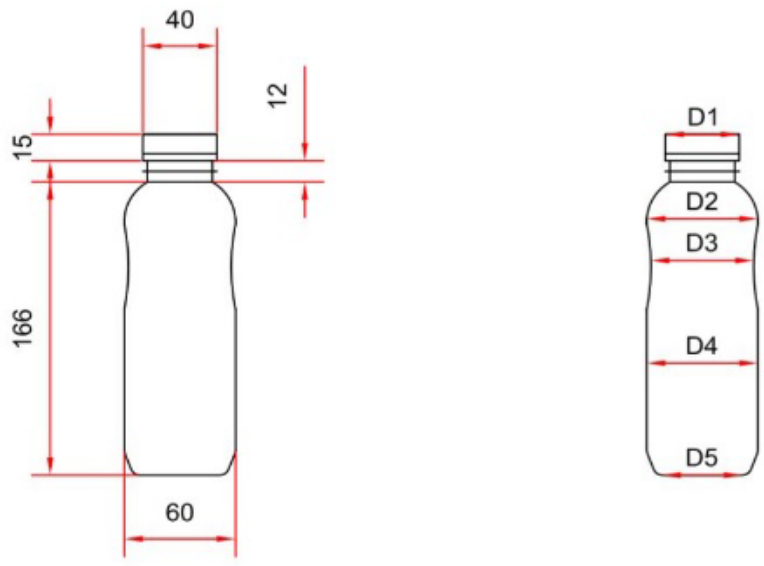

Figure 2 Dimensions of a $500 \mathrm{ml}$ PET bottle in $\mathrm{mm}$ (D1=40; D2=64.65; D3=40.40; D4=64.65; D5=60 mm) 
Table 4 Snapshots of tests of $500 \mathrm{ml}$ single PET bottles

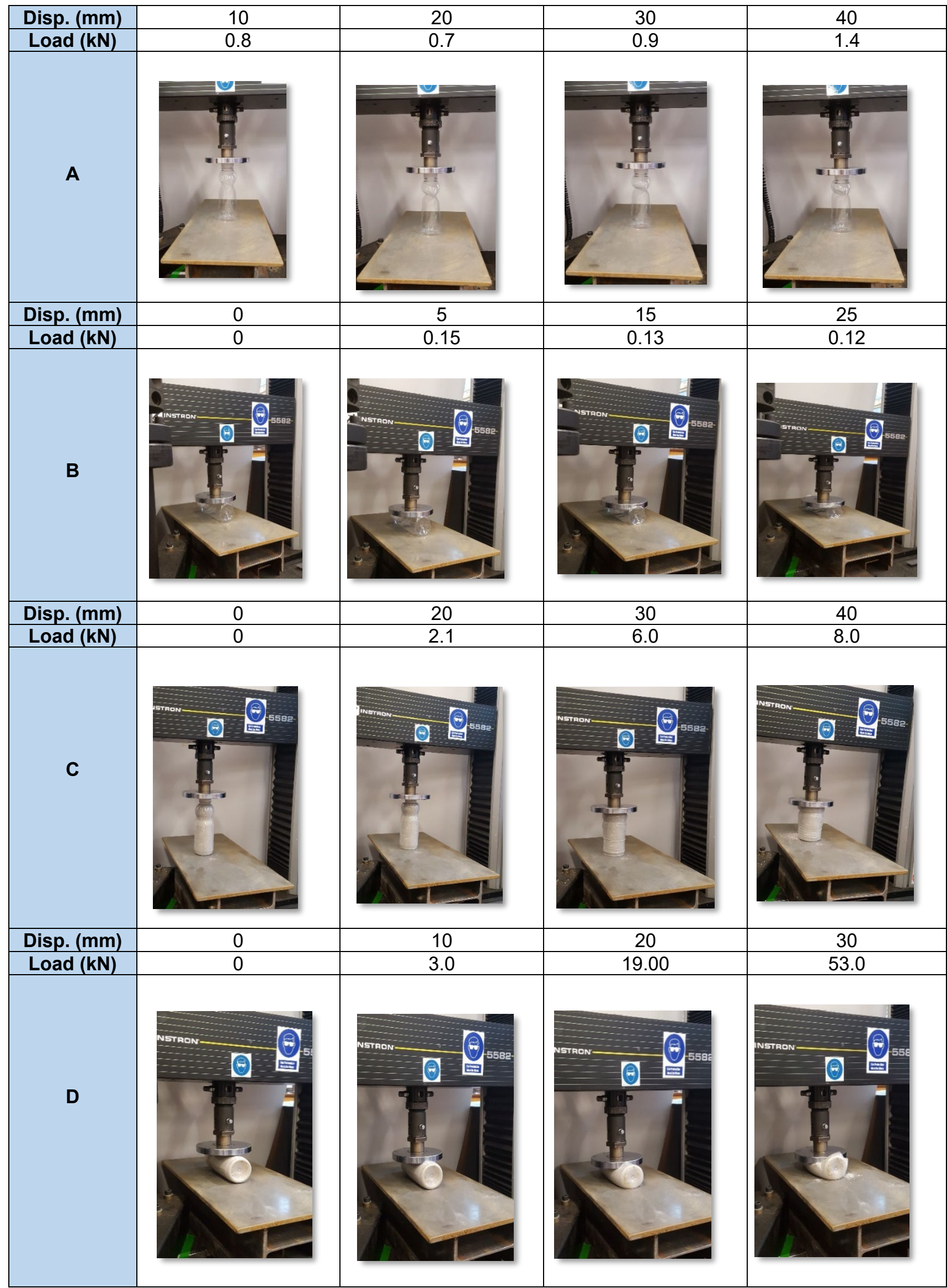


Table 5 Snapshots of tests of a row of six $500 \mathrm{ml} \mathrm{PET} \mathrm{bottles}$

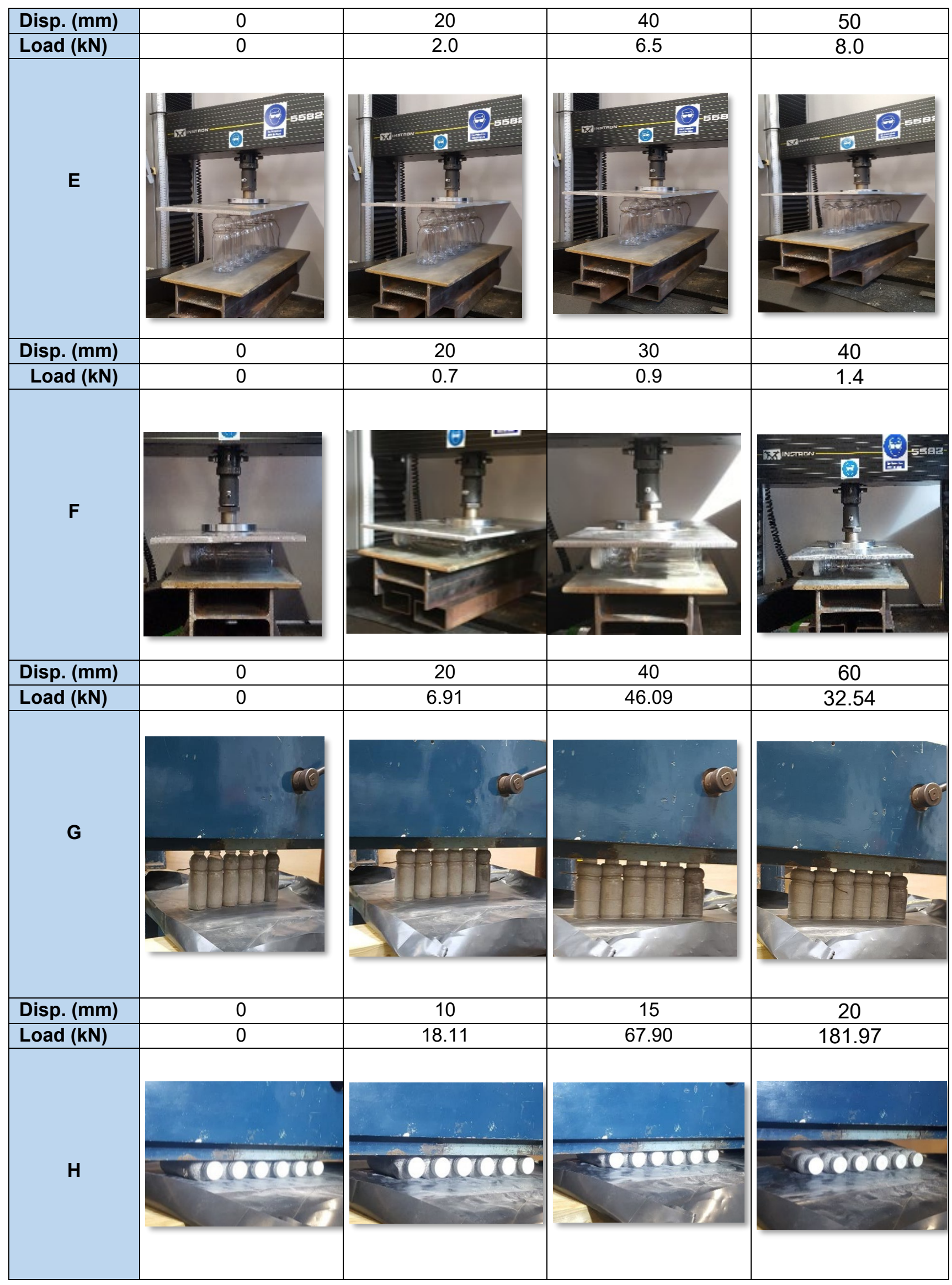




\subsection{Tests of sand-filled plastic bottled clay panels}

Having learnt a lesson from the 'Bottle House' project and a recommendation from Oyinlola et al. (2018), it was necessary to utilise more sustainable local material. Hence, a daub and bottle panel design was incorporated in this study. Once built, such panels could be installed in a modular fashion for the wall and/or floor panels of a building. They have the potential to significantly reduce the time of construction. A total of twelve panels: six with plastic bottles and six without plastic bottles were prepared and tested to investigate the structural behaviour of such panels. Figure 3 shows a process from design to testing of the panels.

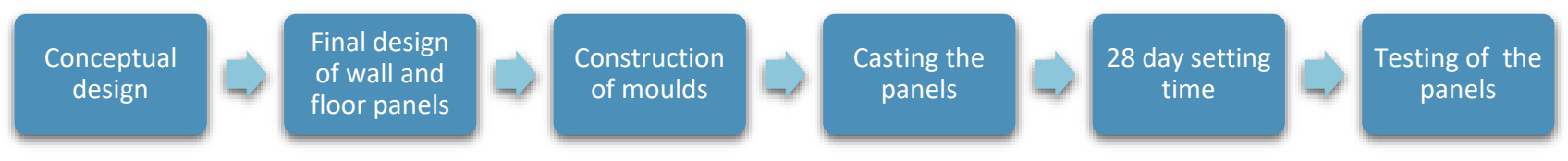

Figure 3 Flow diagram of the experimental work

Figure 4 shows drawings of test specimens. Each panel was $440 \mathrm{~mm} \times 480 \mathrm{~mm} \times 200 \mathrm{~mm}$. Out of the twelve panels, six had staggering rows of six and seven $500 \mathrm{~mm}$ PET bottles, which were filled with dry sands and then tied together with a string. Three panels were cast vertically (wall panels) and the other three were horizontally (floor panels). As the preliminary test showed that clay alone did not harden by the required test date, small amount of a binder was necessary. Hence, 5 percent of cement, CEM1 and 2.5 percent of water, by weight of the clay, were added to a pre-mixed clay called 'daub', which consisted of one part of clay, two parts of coarse pit sand and one part of chopped straw and hay. The mixture was then filled between the bottles in a mould. The remaining six panels: three each for wall and floor panels were cast without bottles, as control sets to those with bottles.

Figures 5 and 6 show casting and testing of the wall and floor panels respectively. The daub mixture was compacted into the moulds using a tamping rod and layered with the sand-filled plastic bottles in a staggered orientation. A layer of approximately $20 \mathrm{~mm}$ was compacted between each row of bottles to ensure consistency of each sample. The compaction of each layer was vital to prevent aeration and cracking. The moulds were removed a week after casting and the panels were stored in a cool, dry area until testing at 28 days after casting. Displacement control, a load of $0.01 \mathrm{~mm}$ per second was used to apply a uniformly distributed load on the wall panels and a point load at the centre of the floor panels. As the load increased, movement of the panels were recorded using Linear Voltage Displacement Transducers (LVDT). The locations of the LVDTs are shown in Figures 5 and 6.

In addition to the twelve panels, eighteen $100 \mathrm{~mm}$ cubes and six $100 \mathrm{~mm}$ diameter, $150 \mathrm{~mm}$ high cylinders were cast to determine the compressive and tensile strength of the daub mixture with $5 \%$ cement. The cubes and cylinders were left to cure in a cool, dry area and tested at $7,14,21,28,84$ and 119 days after casting. Figure 7 shows testing of the cubes and cylinders. 


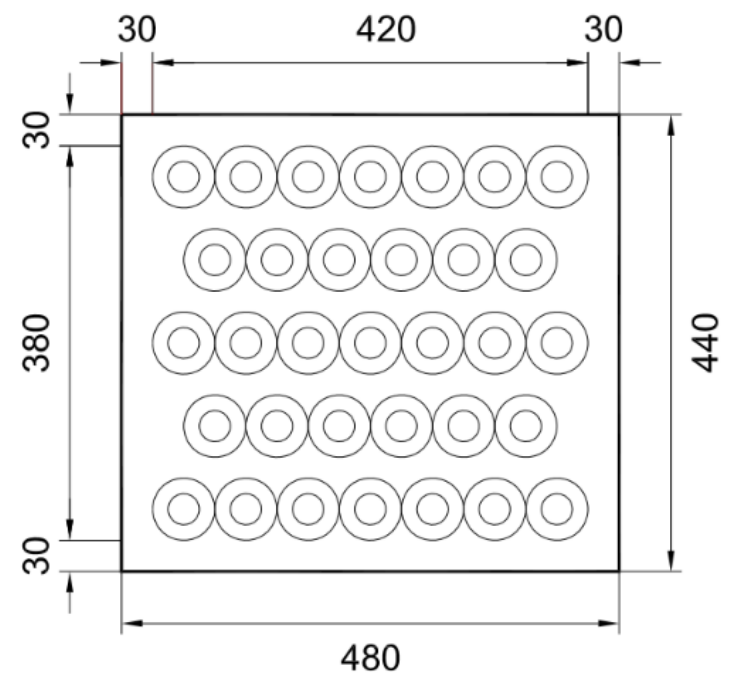

Section of a wall panel

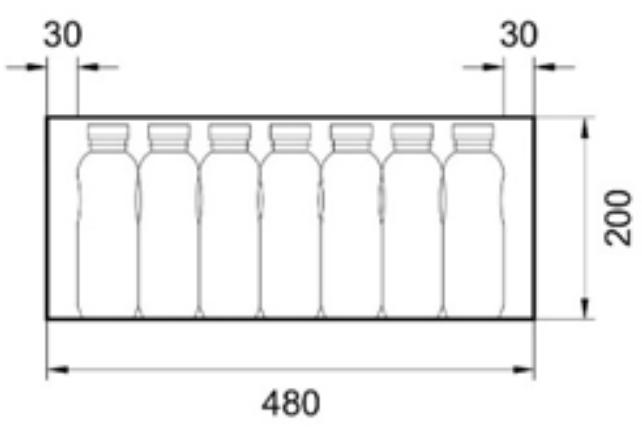

Section of a floor panel

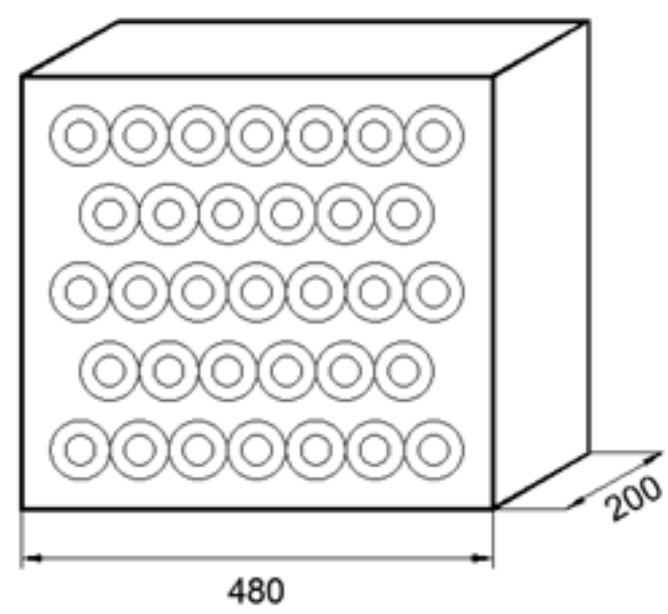

Isometric of a wall panel

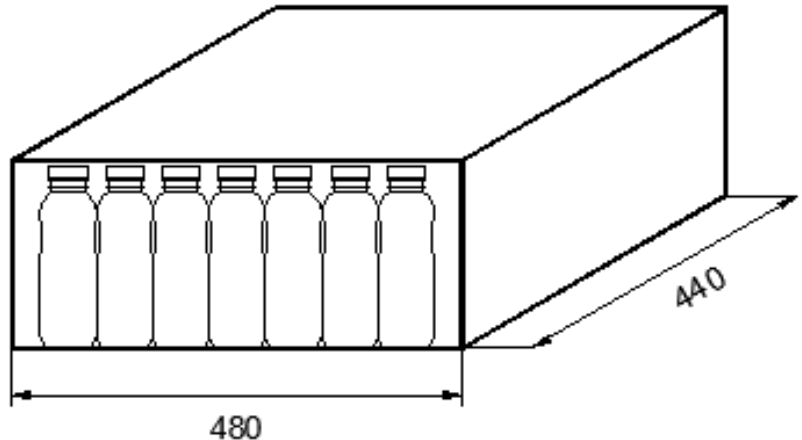

Isometric of a floor panel

Figure 4 Drawings of the test specimens (dimensions are in $\mathrm{mm}$ ) 


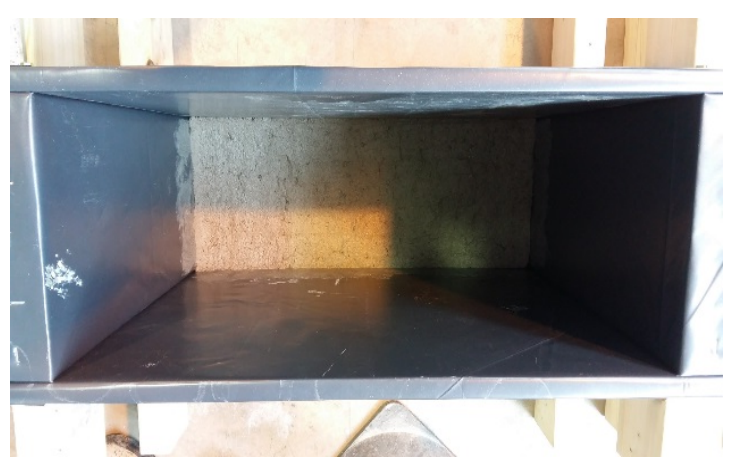

(a) Mould with clay cover

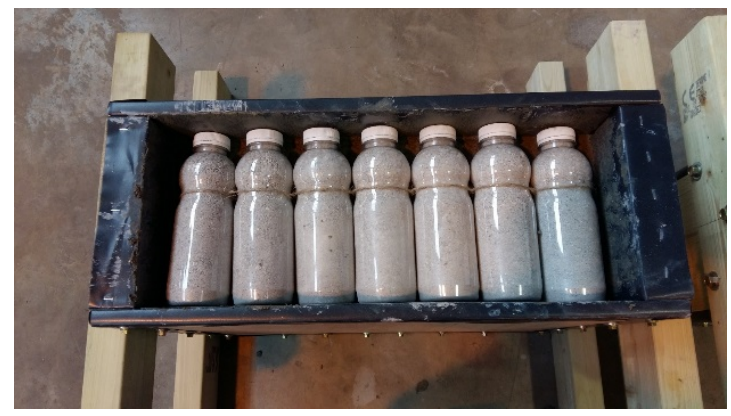

(b) Mould with sand filled PET bottles

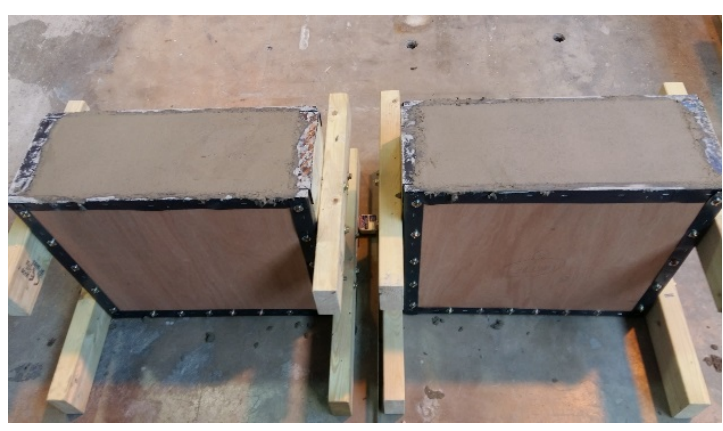

(c) Complete casting

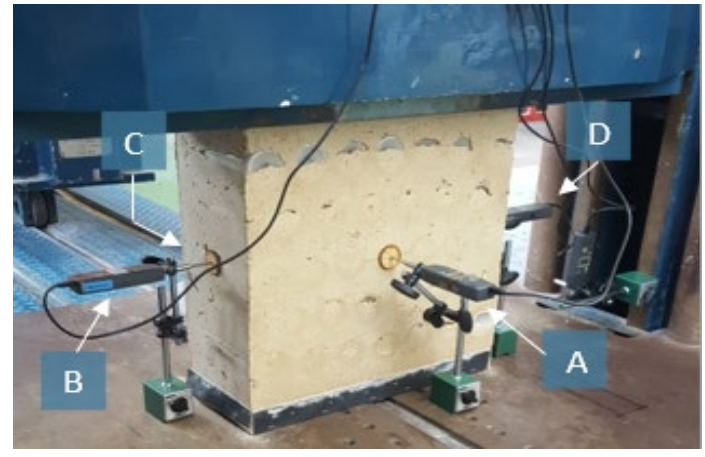

(d) Test set up

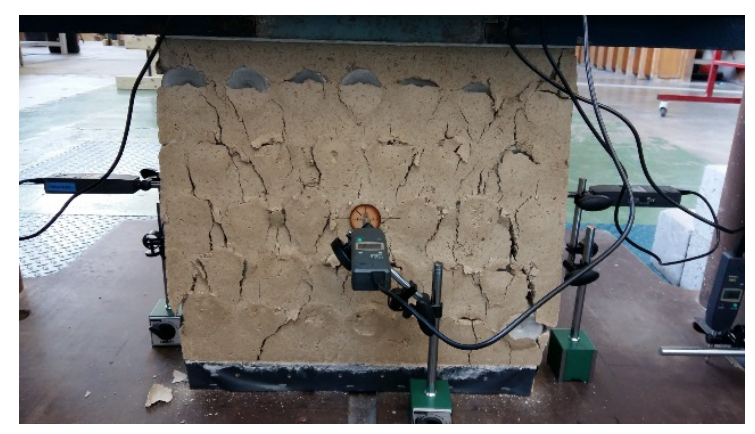

(e) Showing cracks under loading

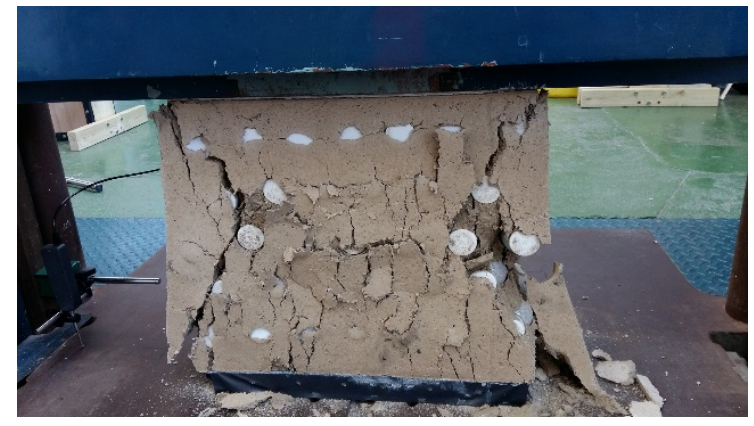

(f) After testing

Figure 5 Casting and testing of sand filled plastic bottled clay wall panels 


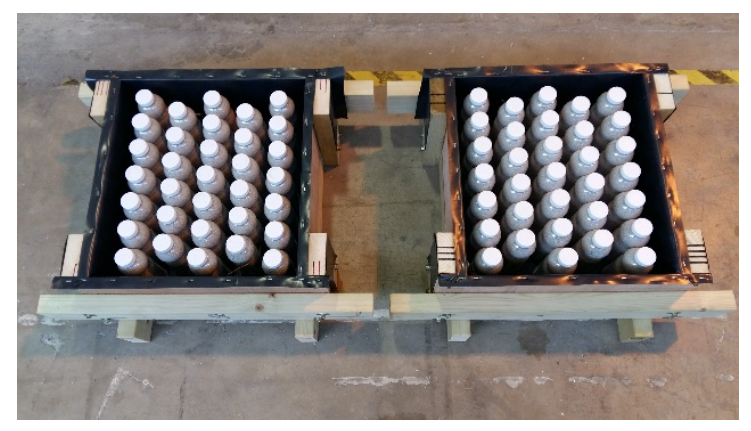

(a) Mould with PET bottles

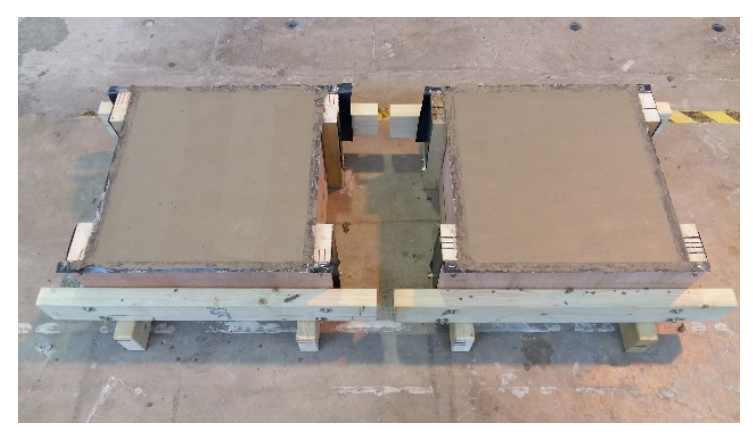

(b) Complete casting

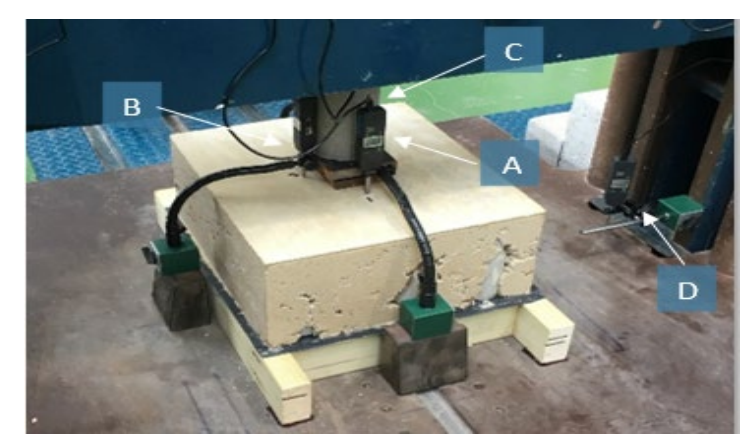

(c) Test set up

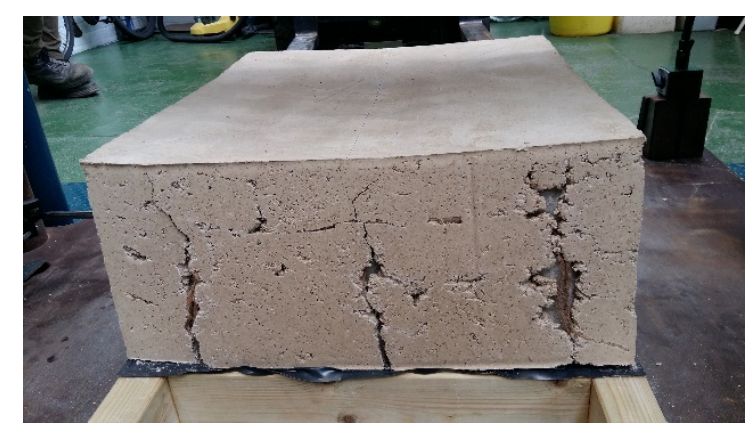

(d) After testing

Figure 6 Casting and testing of sand filled plastic bottled clay floor panels

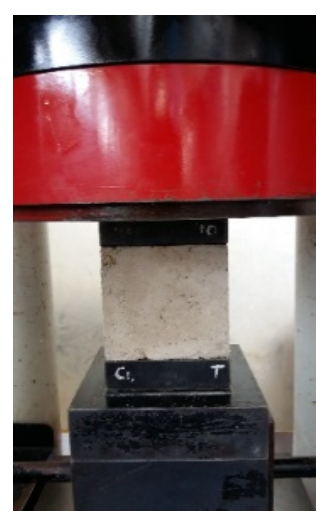

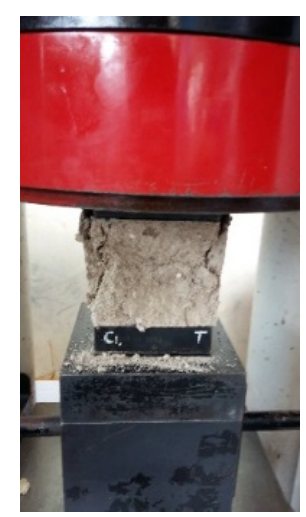

(b) Cube undder loading

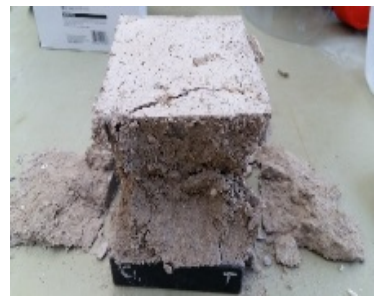

(c) After test

(a) Test set-up for a cube

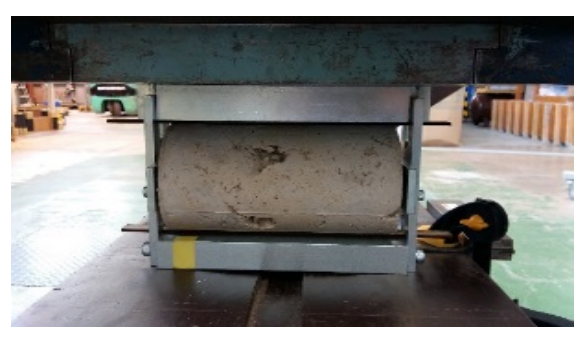

(d) Test set-up for a cylinder

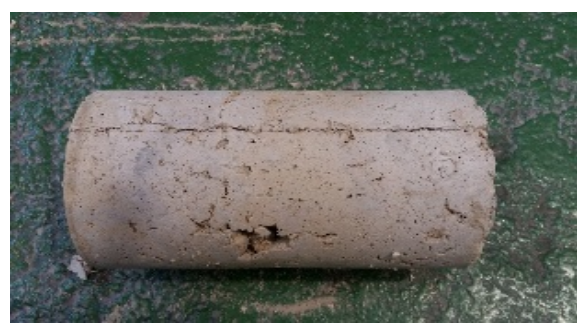

(e) After test

Figure 7 Material strength tests 


\section{Results and Discussion}

\subsection{Tests of $500 \mathrm{ml}$ Polyethylene Terephthalate (PET) bottles}

Table 6 and Figure 8 present the test results of $500 \mathrm{ml}$ PET bottles and their failure modes respectively. For the specimens tested vertically, i.e. Groups A, C, E and G, the yield strengths were calculated using the contact area of the bottle cap (D1 = $40 \mathrm{~mm}$ ). For the specimens tested horizontally, i.e. Groups $B, D, F$ and $H$, yield strengths were calculated using the contact area, which was traced manually over the failed bottles after testing. The contact area of a $500 \mathrm{~mm}$ sand-filled single bottle tested horizontally was $11732 \mathrm{~mm}^{2}$. This is $14 \%$ smaller than that measured in the work by Taaffe, et al. (2014). It should be noted that they used bottles filled with plastic bags, which led to a larger deformation than a sand-filled bottle.

Specimens in Group A showed an early onset cracking and local buckling around the neck of the bottles at an average yielding load of $0.65 \mathrm{kN}$ and its compressive strength of 0.52 $\mathrm{N} / \mathrm{mm}^{2}$. The weakest point of the bottle was at Point D2 of Figure 2 because the compressive force caused the neighbouring materials subject to bending, just like a cantilever with a point load. It produced a brittle form of failure with a permanent damage around Point D2, as shown in Figure 8 (a).

Upon adding dry sands to the bottles in Group C, the average strength was as much as 5.88 $\mathrm{N} / \mathrm{mm}^{2}$. This is 11 times higher than that of the empty bottle. This indicates that the infilled sands made a significant contribution to the strength as they played an important role to distribute the stress evenly across the bottle. This led the bottles to fail in a ductile manner, which is a favourable property in a construction material as the yielding behaviour is noticeable before the ultimate collapse. The bottles busted at Point D2 with a permanent damage and some sands were spilled. Similarly, sand-filled bottles positioned in a vertical row of 6 in Group $\mathrm{G}$ also demonstrated an even distribution of stress across all the bottles, producing an average yield strength of $6.3 \mathrm{~N} / \mathrm{mm}^{2}$. This is 57 times higher than that of a row of 6 empty bottles in Group E. It is worth to note that the outer bottles damaged more than the others and busted with some sand spillage.

The inclusion of in-filled sands also contributed to the strength of the bottles tested horizontally. The average strength of the bottles in Group D was as much as $5.88 \mathrm{~N} / \mathrm{mm}^{2}$. This is 228 times higher than that of the empty bottles in Group B and 2.16 times higher than that of the bottles filled with plastic bags, tested by Taaffe et al. (2014). The latter produced more deformation and hence less stiff than the sand filled ones. This suggests that the sand filled bottles used in this study provide good strength and stiffness, while bottles filled with plastic bags are lighter than sand filled ones. The average yield strengths of the singular infilled bottles and group of 6 bottles are 228 times and 59 times higher than those of empty ones, as shown in Table 6.

The sand-filled, horizontal row of 6 produced the greatest resisting load against deflection of $298.05 \mathrm{kN}$. The test was stopped at approximately $300 \mathrm{kN}$ as the bottle had fully deflected, resulting in the sand being the only resisting component for the Avery machine.

The bottles tested vertically resisted better than those tested horizontally. The biggest winner is Group A, whose yield strength is 26 times greater than that of Group B. Bottles in Group C, E and $\mathrm{G}$ were 1.3 times, 1.6 times and 1.5 times stronger than their counterparts respectively. Hence, bottles should be used vertically if they are to support any loads. 
Table 6 Results of the $500 \mathrm{ml}$ PET bottle tests

\begin{tabular}{|c|c|c|c|c|c|c|c|}
\hline $\begin{array}{l}\text { Specimen } \\
\text { group }\end{array}$ & $\begin{array}{l}\text { Yield } \\
\text { load } \\
\text { (kN) }\end{array}$ & $\begin{array}{l}\text { Ultimate } \\
\text { load } \\
\text { (kN) }\end{array}$ & $\begin{array}{l}\text { Displacement } \\
\text { at the yield } \\
\text { load (mm) }\end{array}$ & $\begin{array}{l}\text { Area } \\
\left(\mathrm{mm}^{2}\right)\end{array}$ & $\begin{array}{c}\text { Yield } \\
\text { strength } \\
\left(\mathrm{N} / \mathrm{mm}^{2}\right)\end{array}$ & Strength c & mparison \\
\hline A1 & 0.57 & 0.68 & 34.10 & \multirow{4}{*}{1256.64} & \multirow{4}{*}{0.52} & \multirow{4}{*}{-} & \multirow{4}{*}{$\begin{array}{c}\text { 26times, } \\
\text { compared } \\
\text { with Group B }\end{array}$} \\
\hline A2 & 0.75 & 1.84 & 35.00 & & & & \\
\hline A3 & 0.63 & 0.9 & 35.03 & & & & \\
\hline Average & 0.65 & 1.14 & 34.71 & & & & \\
\hline B1 & 0.17 & 0.12 & 4.97 & \multirow{4}{*}{9380} & \multirow{4}{*}{0.02} & \multirow{4}{*}{-} & \multirow{4}{*}{ - } \\
\hline B2 & 0.16 & 0.11 & 4.97 & & & & \\
\hline B3 & 0.14 & 0.12 & 4.97 & & & & \\
\hline Average & 0.16 & 0.17 & 4.97 & & & & \\
\hline C1 & 7.35 & 5.43 & 35 & \multirow{4}{*}{1256.64} & \multirow{4}{*}{5.88} & \multirow{4}{*}{$\begin{array}{c}11 \text { times, } \\
\text { compared } \\
\text { with Group A }\end{array}$} & \multirow{4}{*}{$\begin{array}{l}1.3 \text { times, } \\
\text { compared } \\
\text { with Group D }\end{array}$} \\
\hline $\mathrm{C} 2$ & 7.43 & 12.7 & 35 & & & & \\
\hline C3 & 7.4 & 4.56 & 35 & & & & \\
\hline Average & 7.39 & 7.56 & 35 & & & & \\
\hline D1 & 64.65 & 70.80 & 29.73 & \multirow{4}{*}{11732} & \multirow{4}{*}{4.55} & \multirow{4}{*}{$\begin{array}{c}228 \text { times, } \\
\text { compared } \\
\text { with Group B }\end{array}$} & \multirow{4}{*}{-} \\
\hline D2 & 61.87 & 62.19 & 32.72 & & & & \\
\hline D3 & 37.59 & 40.95 & 25.00 & & & & \\
\hline Average & 54.70 & 57.98 & 29.15 & & & & \\
\hline E1 & 0.79 & 1.49 & 7.6 & \multirow{4}{*}{7539.82} & \multirow{4}{*}{0.11} & \multirow{4}{*}{-} & \multirow{4}{*}{$\begin{array}{l}1.6 \text { times, } \\
\text { compared } \\
\text { with Group F }\end{array}$} \\
\hline E2 & 0.81 & 1.62 & 7.5 & & & & \\
\hline E3 & 0.82 & 1.19 & 7.5 & & & & \\
\hline Average & 0.8 & 1.43 & 7.53 & & & & \\
\hline F1 & 5.43 & 7.92 & 33 & \multirow{4}{*}{85525} & \multirow{4}{*}{0.07} & \multirow{4}{*}{ - } & \multirow{4}{*}{ - } \\
\hline F2 & 5.87 & 8.45 & 33 & & & & \\
\hline F3 & 5.87 & 8.3 & 33 & & & & \\
\hline Average & 5.72 & 8.22 & 33 & & & & \\
\hline G1 & 48.62 & 55 & 40 & \multirow{4}{*}{7539.82} & \multirow{4}{*}{6.30} & \multirow{4}{*}{$\begin{array}{c}57 \text { times, } \\
\text { compared } \\
\text { with Group E }\end{array}$} & \multirow{4}{*}{$\begin{array}{l}1.5 \text { times, } \\
\text { compared } \\
\text { with Group F }\end{array}$} \\
\hline G2 & 43.53 & 45 & 42 & & & & \\
\hline G3 & 50.32 & 56 & 42 & & & & \\
\hline Average & 47.49 & 52 & 7.53 & & & & \\
\hline H1 & 300.01 & 300.01 & 23.22 & \multirow{4}{*}{72189} & & & \\
\hline $\mathrm{H} 2$ & 294.13 & 294.13 & 22.26 & & 4.13 & 59 times, & - \\
\hline H3 & 300.00 & 300.00 & 23.52 & & & $\begin{array}{c}\text { compared } \\
\text { with Group F }\end{array}$ & \\
\hline Average & 298.05 & 300.01 & 23.00 & & & & \\
\hline
\end{tabular}




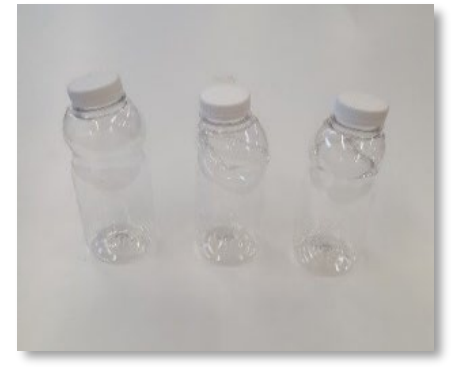

(a) Sepcimen A

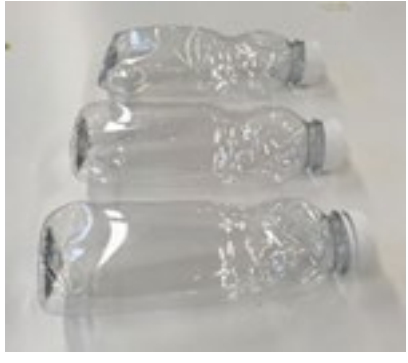

(b) Specimen B

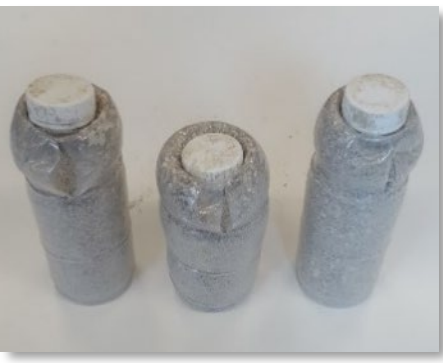

(c) Specimen C

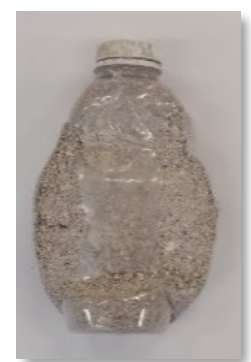

(d) Specimne D

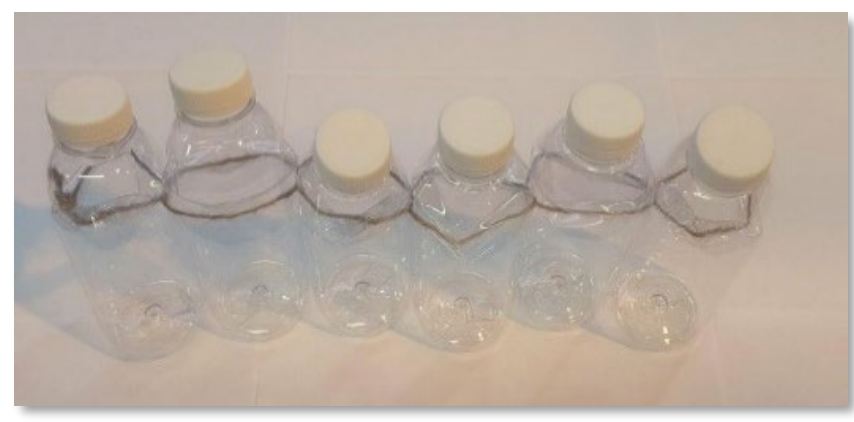

(e) Specimen E

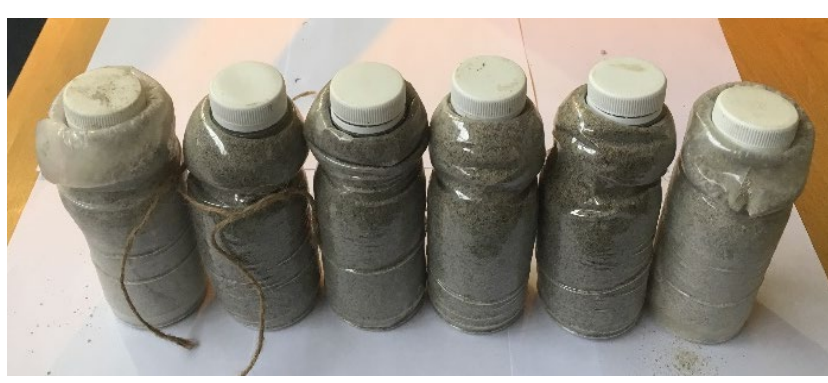

(g) Specimen G

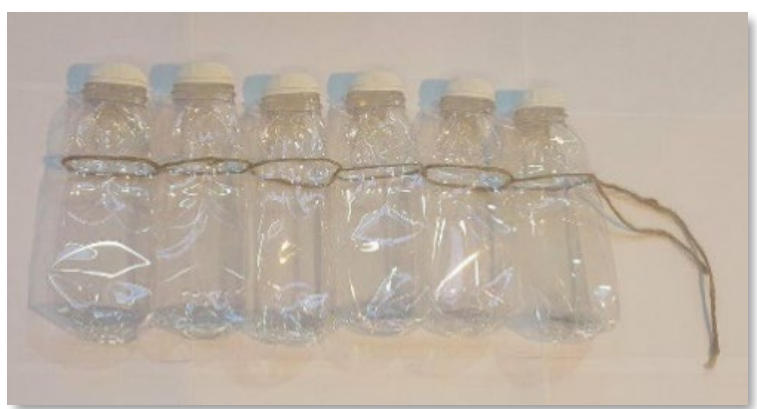

(f) Specimen F

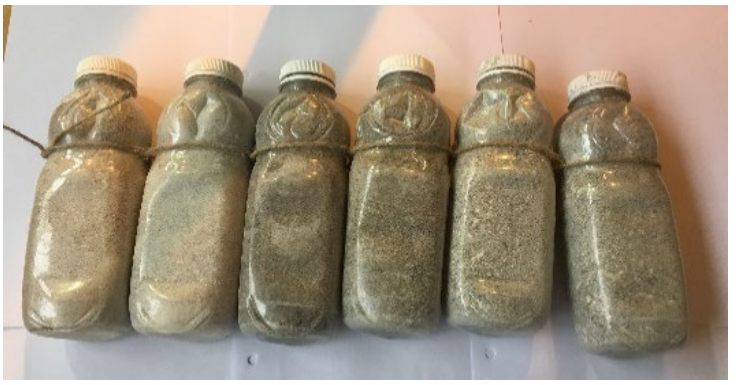

(h) Specimen $\mathrm{H}$

Figure 8 Failure modes of the $500 \mathrm{ml}$ PET bottles

\subsection{Wall panels}

Table 7 presents the test results of the wall panels. The panels with bottles had six and seven sand-filled $500 \mathrm{ml}$ PET bottles in a staggered orientation. It was envisaged that the panels incorporating plastic bottles would fail earlier than the clay alone panels due to the lack of bond between the clay and bottles. This would lead to the separation between them at failure. As the load increased, the tensile stress induced inside of the panel exceeded the tensile strength of the daub and hence numerous cracks gradually appeared on the surface of the panel near the bottles, as shown in Figure 5 (e). Vertical cracks occurred near the centre of the panel, whereas diagonal ones happened from its four corners. The top and bottom diagonal cracks met at near the half height of the panel, as shown in Figure 5 (f). This resembles the failure mode of concrete cubes. After the diagonal cracks meet, they no longer have space to travel and hence lead to a separation between the clay and bottles at collapse. The crack patterns observed in this study differ from the mode of cracking of $300 \mathrm{~mm}$ cement mortar cubes incorporating eight 1.5 litre PET bottles in three layers in the 
work by Mansour and Ali (2015) where a vertical crack initiated from the top centre of the panel and then travelled between bottles, showing a line of an inverted v-shape. The difference in the failure modes of the two studies could be because firstly, the clay used in this study caused earlier cracking due to its low tensile strength, compared with cement mortar used in the study by Mansour and Ali (2015). Secondly, the bottles used by Mansour and Ali were not fully embedded in the cement mortar. Bottle caps and their vicinity were exposed for aesthetic reasons. This resulted in cracks starting from the centre of the top layer of the mortar, rather than near bottles.

As expected, the panels incorporating the plastic bottles obtained lower strength that that of the clay alone panels, i.e. without plastic bottles. Their average yield strength is as much as $0.15 \mathrm{~N} / \mathrm{mm}^{2}$. This is about a quarter strength of the daub only panels. Walls built using sand filled plastic bottles (Oyinlola et al., 2018) are usually one metre wide and mainly support their self-weight and a very light roof if they are external. Hence, the yield strength of 0.15 $\mathrm{N} / \mathrm{mm}^{2}$ could be sufficient.

The daub only panels were stiff, compact and cohesive mixtures, which provided a strong interlocking mechanism between clay and cement particles. While, the panels with the bottles had early signs of cracks, evident in the vicinity of their longitudinal edges. As the load increased, the daub surrounding the plastic bottles at the longitudinal edges separated from the panel, as shown in Figure 9 (a), due to a lack of cohesion from the bottle and daub. Further, the separation could also be because of differences in the modulus of elasticity of the daub and bottles. The modulus of elasticity of PET plastics is about 2.3 GPa (Crompton, 2012) where that of soft clay is between 5 to $25 \mathrm{MPa}$ (Subramanian, 2016). PET plastic is therefore about 100 times stiffer than soft clay. This significant difference in stiffness could have contributed to increase the tensile stress in the panel, as suggested by Mansour and Ali (2015).

After testing, the condition of the plastic bottles were examined. They were not deformed or damaged. This suggests that a negligible amount of load was taken by the bottles and hence the load was primarily taken by the daub. This also indicates that the panels failed due to a lack of bond between the two materials. If the bottles and daub could interlock effectively, then the applied load would transfer into the bottles, which would potentially improve the compressive strength of the panels. Methods to improve the bond between the clay and bottles should be explored.

Figure 10 shows the load-displacement relationship of the wall panels. The daub only panels yielded at approximately $0.4 \mathrm{~mm}$ and demonstrated brittle characteristics, having little plastic deformation or energy absorption before failure. A brittle material is likely to result in a dangerous and sudden collapse, with little warning, which is an unfavourable characteristic in construction. Whereas, the panels with sand-filled plastic bottles found to be ductile because after yielding they sustained the load with increasing displacements before failure. Because of the separation of the bottles from the clay, the longitudinal edges deflected about three times more than transvers edges at the ultimate load. Gauges B and D deflected an average of $23.41 \mathrm{~mm}$ and $21.66 \mathrm{~mm}$ respectively, compared with Gauges A and C deflecting an average of $6.63 \mathrm{~mm}$ and $9.07 \mathrm{~mm}$. 
Table 7 Compressive strength of the wall panels

\begin{tabular}{|c|c|c|c|c|c|c|c|}
\hline & $\begin{array}{l}\text { Specimen } \\
\text { Number }\end{array}$ & $\begin{array}{c}\text { Age } \\
\text { (days) }\end{array}$ & $\begin{array}{l}\text { Yield } \\
\text { load } \\
(\mathrm{kN})\end{array}$ & $\begin{array}{l}\text { Ultimate } \\
\text { load } \\
(\mathrm{kN})\end{array}$ & $\begin{array}{l}\text { Area } \\
\left(\mathrm{mm}^{2}\right)\end{array}$ & $\begin{array}{c}\text { Compressive } \\
\text { strength* } \\
\left(\mathrm{N} / \mathrm{mm}^{2}\right)\end{array}$ & $\begin{array}{l}\text { Average } \\
\text { strength* } \\
\left(\mathrm{N} / \mathrm{mm}^{2}\right)\end{array}$ \\
\hline \multirow{3}{*}{$\begin{array}{c}\text { With } \\
\text { bottles }\end{array}$} & 1 & 28 & 13.80 & 29.83 & 96000 & 0.14 & \multirow{3}{*}{0.15} \\
\hline & 2 & 28 & 14.13 & 24.67 & 96000 & 0.15 & \\
\hline & 3 & 28 & 13.97 & 22.14 & 96000 & 0.15 & \\
\hline \multirow{3}{*}{$\begin{array}{l}\text { Without } \\
\text { bottles }\end{array}$} & 1 & 28 & 55.04 & 60.31 & 96000 & 0.57 & \multirow{3}{*}{0.63} \\
\hline & 2 & 28 & 63.61 & 72.11 & 96000 & 0.66 & \\
\hline & 3 & 28 & 63.32 & 72.08 & 96000 & 0.66 & \\
\hline
\end{tabular}

*at the yield load.
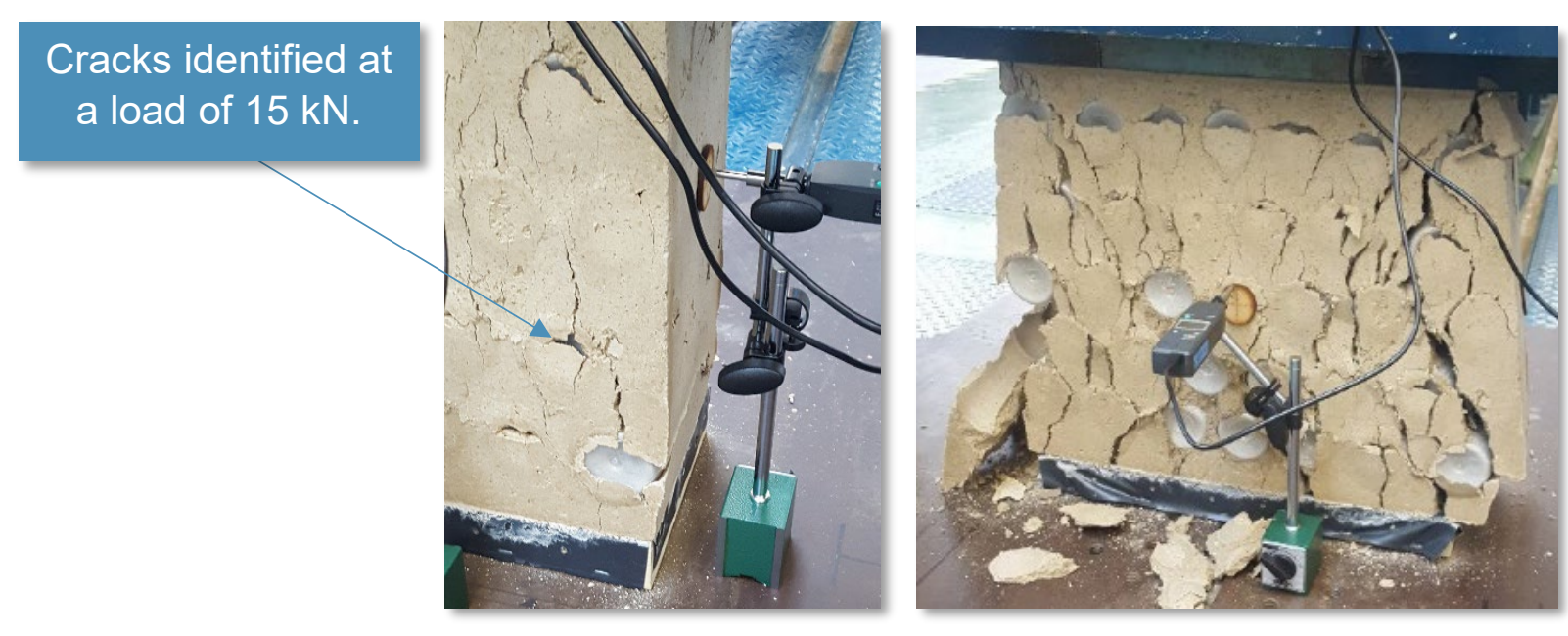

(a) Wall panels
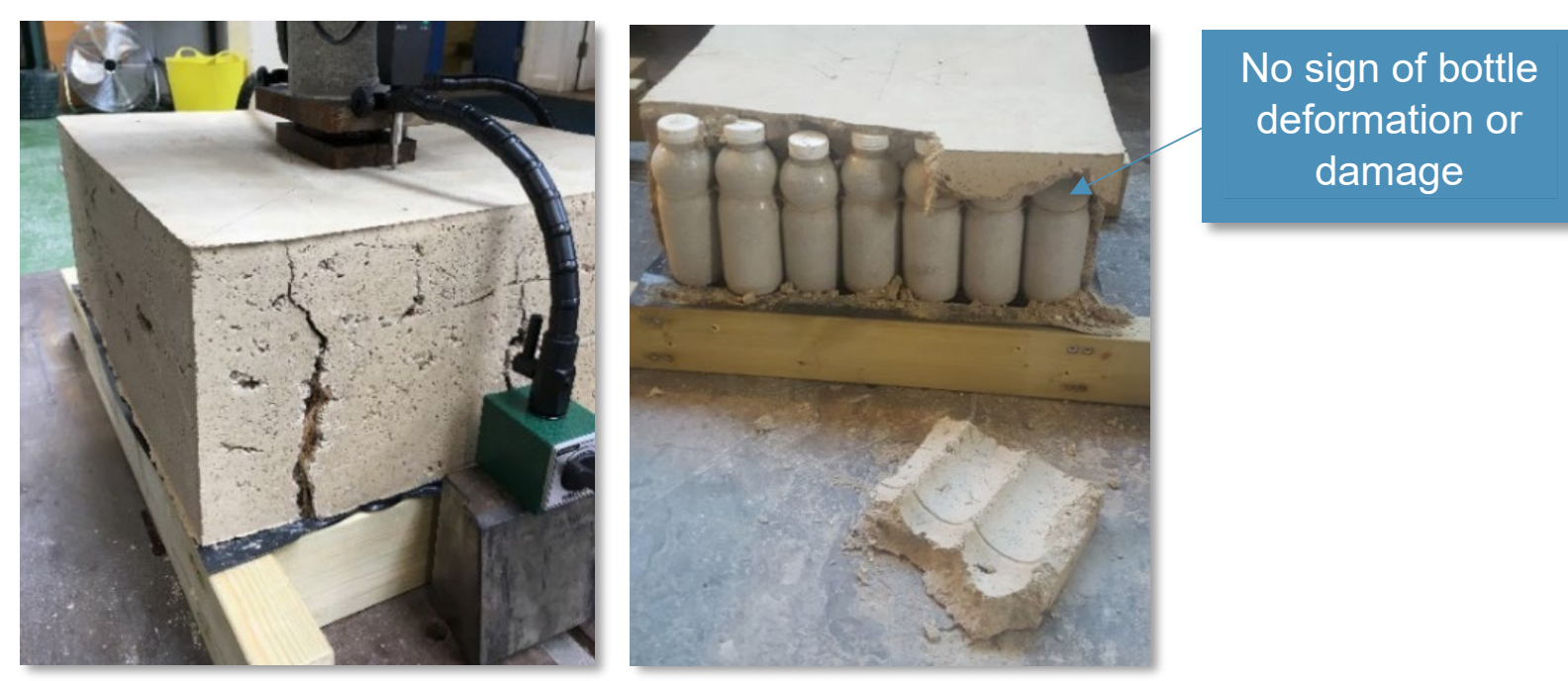

(b) Floor panels

Figure 9 Failure modes of the panels with sand-filled bottles 


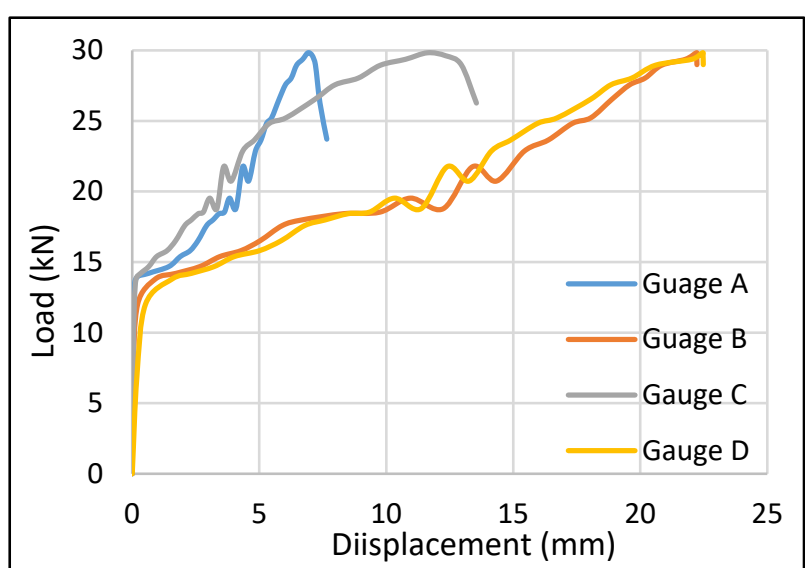

Specimen 1

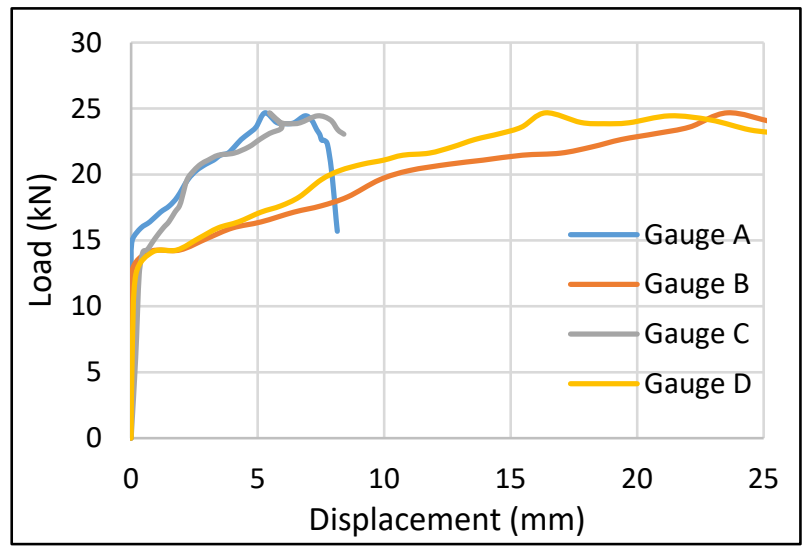

Specimen 2

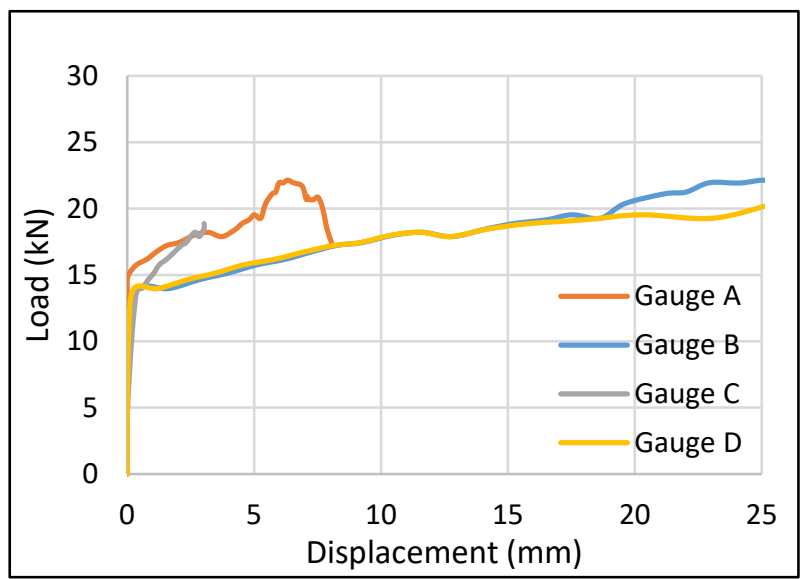

Specimen 3

(a) with sanded-filled plastic bottles

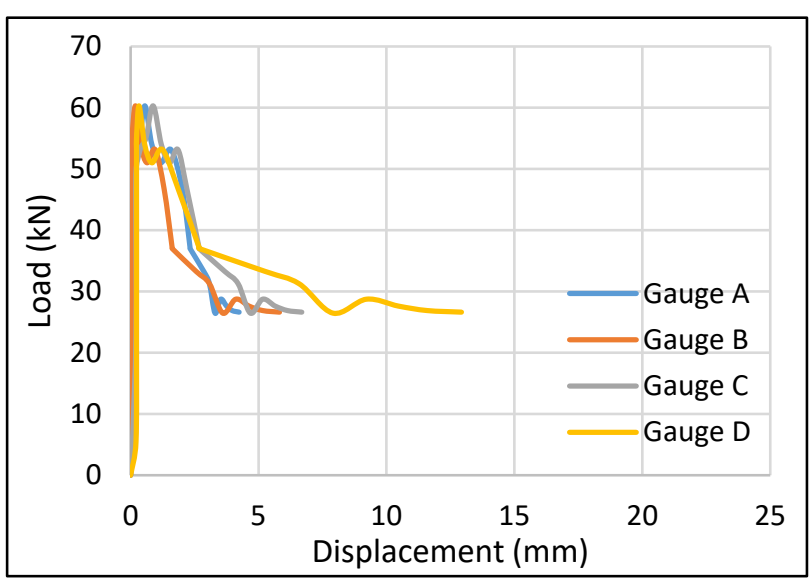

Specimen 1

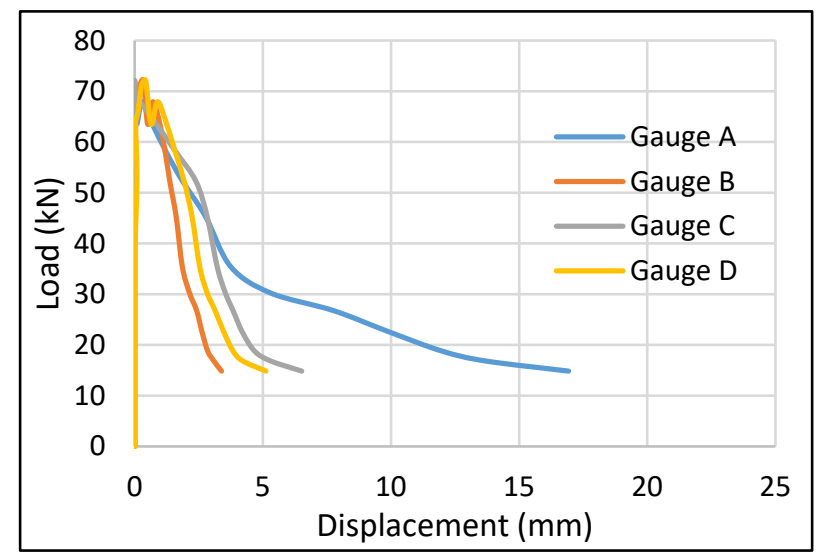

Specimen 2

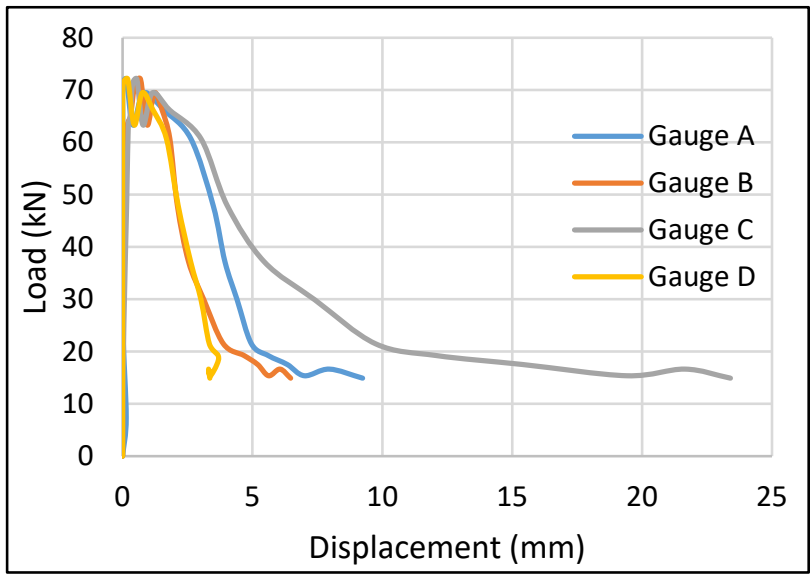

Specimen 3

(b) without bottles

Figure 10 Load-displacement relationship of the wall panels 


\subsection{Floor panels}

Thick floor slabs would provide effective insulation for hot climates such as in Nigeria (Suhalia et al., 2016), as the daub and bottles would buffer the house from intense heat. Table 8 compares the test results of the floor panels with and without six and seven sandfilled $500 \mathrm{ml}$ PET bottles in a staggered orientation. The panels incorporating the plastic bottles obtained an average bending strength of $0.12 \mathrm{~N} / \mathrm{mm}^{2}$, with a displacement of $0.85 \mathrm{~mm}$ at the yielding load. While, the daub only panels attained an average bending strength of $0.53 \mathrm{~N} / \mathrm{mm}^{2}$, with a displacement of $0.30 \mathrm{~mm}$. Hence, as expected, the panels with the bottles achieved about a quarter bending strength of the daub only panels.

It should be noted that test results for clay panels with plastic bottles subject to bending are practically non-existent. As shown in Figure 9 (b), vertical cracks occurred on the tension (bottom) side of the slabs. As the load increased, the tensile cracks increased in both length and thickness. As the load increased further, the edge daub was separated from the bottles, leading to a drastic failure. The separation was assumed to be due to a relatively low tensile bond strength between the bottles and daub, which was the weakest link and hence resulted in a detrimental effect on the slab.

In the absence of comparable test results for clay wall panels subject to bending, analogous situations must be considered. For example, the study of the tensile behaviour of the masonry-mortar interface by Lourenço (1998) included three-point bending, which is the same loading arrangement for the slab panels used in this study. Lourenço concluded that there existed two failure modes, depending on the relative strength of the masonry units and joints. If the joint is weaker than the masonry, the cracks zigzag along the joints. If the joint is strong enough, vertical cracks occur as if the panel is made of one material. In the present study, because the daub was weaker than the bottles, cracks occurred in the daub, which separated from the bottles.

After testing, the bottles were examined. Like the wall panels, the bottles were intact. This suggests that the load was resisted primarily by the daub and little contribution was made by the bottles. This also suggests that the panels failed by a lack of bond between the daub and bottles. The panels had staggering rows of six and seven bottles. The bottles for each row were tied together with a string and hence had no space between them. If the daub was filled between the bottles and hence individual bottles were surrounded by the daub, the bond failure could have been delayed and therefore the panel could have sustained the load longer.

Figure 11 shows the load-displacement relationship of the floor panels. The daub only panels yielded at a deflection of approximately $0.3 \mathrm{~mm}$ and the load decreased sharply. On the other hand, the panels with bottles yielded at a deflection of $0.85 \mathrm{~mm}$ and failed in a slightly more ductile manner than the daub only panels. 
Table 8 Bending strength of the floor panels

\begin{tabular}{|c|c|c|c|c|c|c|c|c|}
\hline & $\begin{array}{l}\text { Specimen } \\
\text { Number }\end{array}$ & $\begin{array}{c}\text { Age } \\
\text { (days) }\end{array}$ & $\begin{array}{l}\text { Yield } \\
\text { load } \\
(\mathrm{kN})\end{array}$ & $\begin{array}{l}\text { Ultimate } \\
\text { load } \\
\text { (kN) }\end{array}$ & $\begin{array}{l}\text { Moment } \\
(\mathrm{N} \mathrm{m})\end{array}$ & $\begin{array}{c}\text { Section } \\
\text { Modulus } \\
\left(\times 10^{3}\right. \\
\left.\mathrm{mm}^{3}\right)\end{array}$ & $\begin{array}{l}\text { Bending } \\
\text { strength* } \\
\left(\mathrm{N} / \mathrm{mm}^{2}\right)\end{array}$ & $\begin{array}{l}\text { Average } \\
\text { strength* } \\
\left(\mathrm{N} / \mathrm{mm}^{2}\right)\end{array}$ \\
\hline \multirow{3}{*}{$\begin{array}{l}\text { With } \\
\text { bottles }\end{array}$} & 1 & 28 & 3.12 & 3.12 & 374 & 2933 & 0.13 & \multirow{3}{*}{0.12} \\
\hline & 2 & 28 & 3.17 & 3.17 & 380 & 2933 & 0.13 & \\
\hline & 3 & 28 & 2.54 & 3.52 & 305 & 2933 & 0.10 & \\
\hline \multirow{3}{*}{$\begin{array}{l}\text { Without } \\
\text { bottles }\end{array}$} & 1 & 28 & 15.37 & 15.37 & 1844 & 2933 & 0.63 & \multirow{3}{*}{0.53} \\
\hline & 2 & 28 & 12.77 & 12.77 & 1532 & 2933 & 0.52 & \\
\hline & 3 & 28 & 10.69 & 10.69 & 1283 & 2933 & 0.44 & \\
\hline
\end{tabular}

${ }^{*}$ at the yield load. 


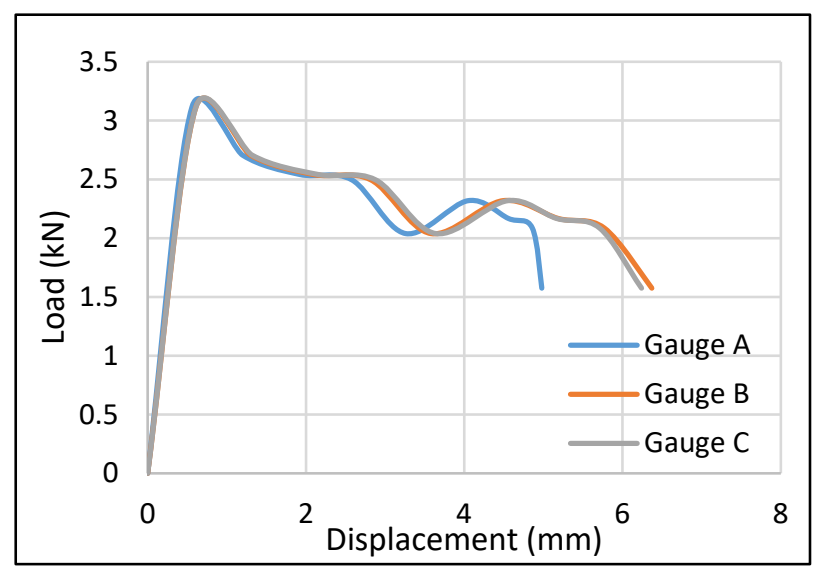

Specimen 1

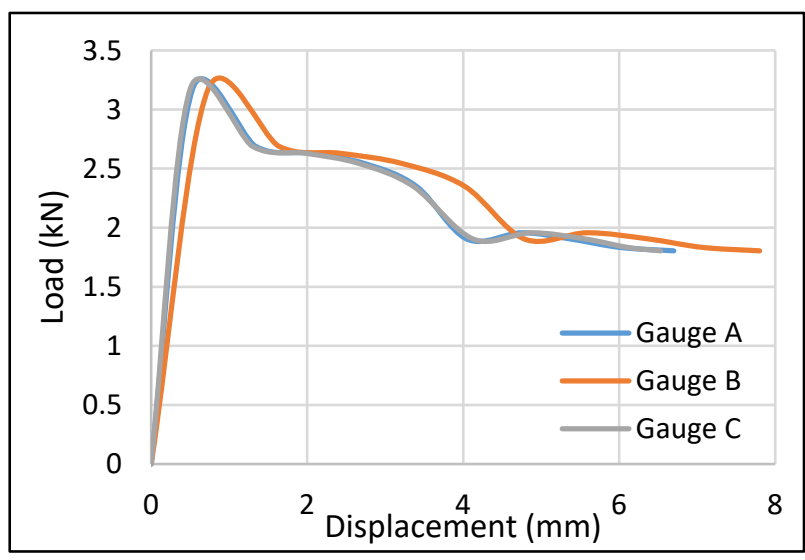

Specimen 2

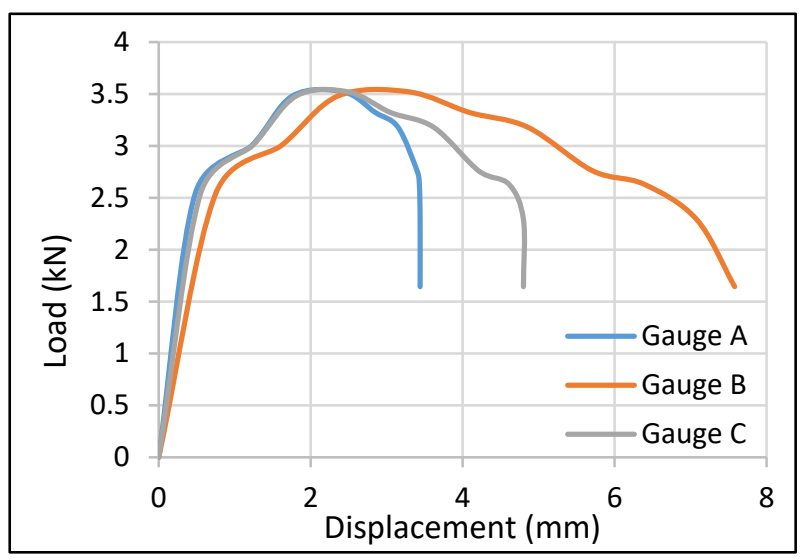

Specimen 3

(a) with sanded-filled plastic bottles

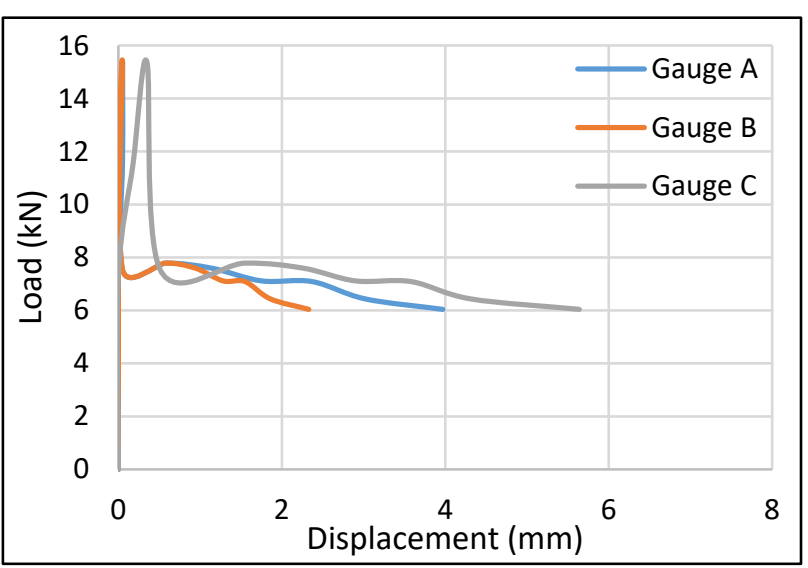

Specimen 1

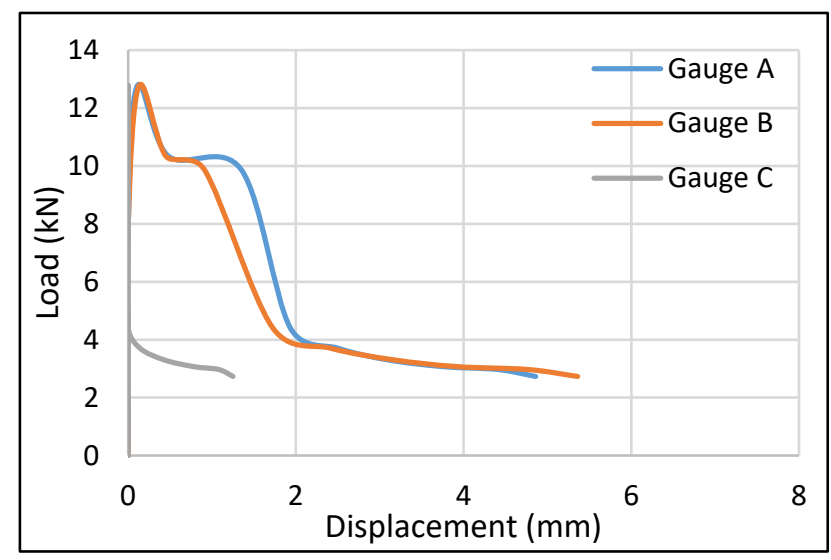

Specimen 2

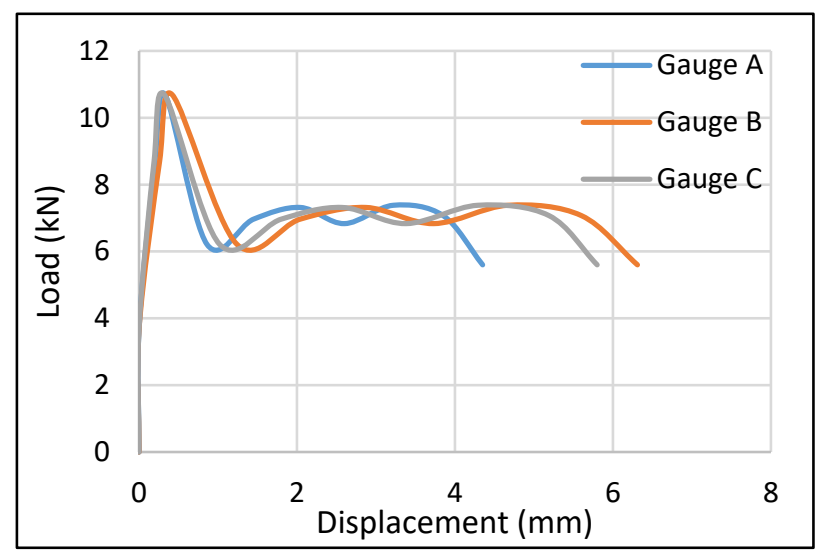

Specimen 3

(b) without bottles

Figure 11 Load-displacement relationship of the floor panels 


\subsection{Strength of the daub mixture with $5 \%$ cement}

Tables 9 and 10 present the compressive strength and tensile strength of the daub mixture with $5 \%$ of cement by weight of daub respectively. Figure 12 shows the compressive strengths of the daub at various ages after casting. Generally, the strength increased with age. The seven-day strength is approximately $64 \%$ of that at 28 days. It is noticeable that the 84 -day strength is $40 \%$ more than that at 28 days. The 119 -day strength was about $2 \%$ lower than the 84-day strength. More tests are required to investigate the daub strength at beyond 119 days.

Table 9 Results of the daub cube tests with $5 \%$ of cement by weight of daub

\begin{tabular}{|c|c|c|c|c|c|}
\hline $\begin{array}{l}\text { Specimen } \\
\text { Number }\end{array}$ & $\begin{array}{c}\text { Age } \\
\text { (days) }\end{array}$ & $\begin{array}{l}\text { Crushing load } \\
\qquad(\mathrm{kN})\end{array}$ & $\begin{array}{c}\text { Compressive } \\
\text { strength } \\
\left(\mathrm{N} / \mathrm{mm}^{2}\right)\end{array}$ & $\begin{array}{l}\text { Average } \\
\text { strength } \\
\left(\mathrm{N} / \mathrm{mm}^{2}\right)\end{array}$ & $\begin{array}{c}\text { Comparison } \\
\text { against at } 28 \\
\text { days }\end{array}$ \\
\hline 1 & 7 & 5.90 & 0.59 & \multirow[t]{2}{*}{0.58} & \multirow{2}{*}{0.64} \\
\hline 2 & 7 & 5.60 & 0.56 & & \\
\hline 3 & 14 & 8.80 & 0.88 & \multirow[t]{2}{*}{0.76} & \multirow[t]{2}{*}{0.84} \\
\hline 4 & 14 & 6.40 & 0.64 & & \\
\hline 5 & 21 & 9.60 & 0.96 & \multirow[t]{2}{*}{0.91} & \multirow[t]{2}{*}{1.01} \\
\hline 6 & 21 & 8.60 & 0.86 & & \\
\hline 7 & 28 & 10.30 & 1.03 & \multirow{6}{*}{0.90} & \multirow{6}{*}{1.0} \\
\hline 8 & 28 & 9.80 & 0.98 & & \\
\hline 9 & 28 & 9.60 & 0.96 & & \\
\hline 10 & 28 & 8.20 & 0.82 & & \\
\hline 11 & 28 & 8.20 & 0.82 & & \\
\hline 12 & 28 & 8.10 & 0.81 & & \\
\hline 13 & 84 & 11.9 & 1.19 & \multirow{3}{*}{1.26} & \multirow{3}{*}{1.40} \\
\hline 14 & 84 & 13.5 & 1.35 & & \\
\hline 15 & 84 & 12.3 & 1.23 & & \\
\hline 16 & 119 & 12.6 & 1.26 & \multirow{3}{*}{1.23} & \multirow{3}{*}{1.37} \\
\hline 17 & 119 & 12.9 & 1.29 & & \\
\hline 18 & 119 & 11.4 & 1.14 & & \\
\hline
\end{tabular}

Table 10 Results of the cylinder tests

\begin{tabular}{|c|c|c|c|c|}
\hline $\begin{array}{c}\text { Specimen } \\
\text { Number }\end{array}$ & $\begin{array}{c}\text { Age } \\
\text { (days) }\end{array}$ & $\begin{array}{c}\text { Breaking load } \\
(\mathrm{kN})\end{array}$ & $\begin{array}{c}\text { Tensile strength } \\
\left(\mathrm{N} / \mathrm{mm}^{2}\right)\end{array}$ & $\begin{array}{c}\text { Average strength } \\
\left(\mathrm{N} / \mathrm{mm}^{2}\right)\end{array}$ \\
\hline 1 & 28 & 3.72 & 0.12 & \multirow{2}{*}{0.12} \\
\hline 2 & 28 & 3.63 & 0.12 & \\
\hline 3 & 28 & 3.98 & 0.13 & \multirow{2}{*}{0.13} \\
\hline 4 & 29 & 4.47 & 0.14 & \\
\hline 5 & 29 & 4.63 & 0.14 & \\
\hline 6 & 29 & 3.77 & 0.12 & \\
\hline
\end{tabular}




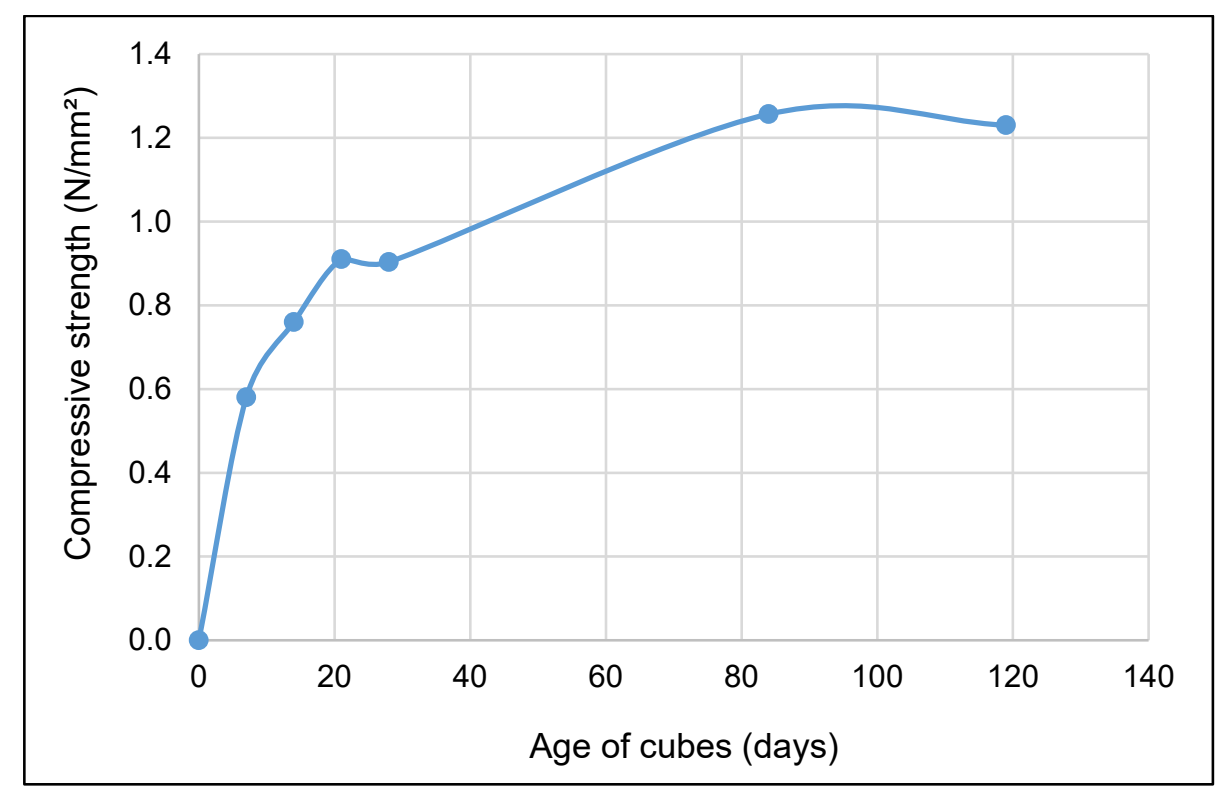

Figure 12 Compressive strength of the daub with age

\subsection{Potentials of sand-filled plastic bottled panels}

Although the daub only panels demonstrated greater compressive and bending strengths, the bottle and daub panels showed ductility, which is a favourable characteristic as visible plastic deformation can be physically identified, allowing users to exit the building before collapse. It was shown in Table 6 that a row of six sand-filled plastic bottles, tested vertically (Group $\mathrm{G}$ ) and horizontally (Group $\mathrm{H}$ ), produced the yield strengths of $6.3 \mathrm{~N} / \mathrm{mm}^{2}$ and 4.13 $\mathrm{N} / \mathrm{mm}^{2}$ respectively. This demonstrates potential for panels with sand-filled bottles to be used for construction if the cohesion of the daub and bottles was sufficient. As the bottles tested vertically attained a better strength than those tested horizontally, the panels should ideally be made with bottles standing up, rather than lying down. By manufacturing panels with bottles in a modular fashion would lead to fast construction on site. Furthermore, it presents an opportunity for the panels to be constructed off site by trained individuals, thereby improving the employment of local communities. By utilising low-cost plastic bottles as a construction material, the overall costs of building a house in rural areas of Nigeria would significantly reduce, creating more affordable housing for people in poverty to live in. In addition, the construction of a bottled panel would reduce the amount of disposed plastic bottles, which currently contributes to the 3000 tonnes of waste produced daily in Abuja (Oyeniyi 2011).

\section{Conclusions}

Physical tests were carried out on $500 \mathrm{ml}$ empty and sand-filled PET bottles, six wall and six floor panels with and without six and seven sand-filled $500 \mathrm{ml}$ PET bottles in a staggered orientation, as well as cubes and cylinders to investigate their behaviour and strengths. From the test results and observations, the following conclusions can be drawn:

- In-filled sands played an important role to distribute the stress evenly across the bottle and hence made a significant contribution to the compressive strength of the PET bottles. The strength increases are as much as 11 and 228 times for single bottles 
and 57 and 59 times for a row of six bottles when tested vertically and horizontally respectively, compared with empty bottles.

- The bottles tested vertically resisted better than those tested horizontally. The strength increase is as much as $26,1.3,1.6$ and 1.5 times for empty single, sandfilled single, a row of six empty and a row of six sand-filled bottles respectively, compared with their counterparts. Therefore, bottles should be standing up, rather than lying down in a wall panel.

- The panels with the sand-filled $500 \mathrm{ml}$ PET bottles obtained about a quarter compressive and bending strengths of those of the daub only panels before they failed by a lack of bond between the daub and bottles. The lack of cohesion between the two materials led to the bottles separated from the daub. The separation could also be because of significant differences in the modulus of elasticity of the daub and bottles, which led to increase the tensile stress in the panel.

- The panels with bottles failed in a ductile manner, while the daub only panels in a brittle manner. After testing, the bottles are found intact and hence they could be reused.

\section{Acknowledgements}

This research was funded by the Royal Academy of Engineering: Frontier's of Engineering - Seed Funding. The authors would like to thank the Academy for their financial support. The authors would also like to thank the technical staff at the Materials, Heavy Structures and Materials Characterisation Laboratories at the University of Plymouth.

\section{Author Contributions}

Boksun Kim and Muyiwa Oyinlola obtained the research grant and conceived the experiments; Boksun Kim, Josef Wisniewski and Toby Baker designed and performed the experiments and analysed the results; All authors contributed to the manuscripts. 


\section{References}

1 Crompton, T.R. Physical testing of plastics, Smithers Rapra Technology, 2012.

2 Habitat. Rehabilitating Urban Slums. Rebuilding Rural Homes. Tackling the Global Housing Crisis. <https://www.habitatforhumanity.org.uk/what-we-do/where-wework/building-and-renovating-homes>, 2017. (date of access 29.09.2017).

3 Mansour, A.M.H. \& Ali, S.A. Reusing waste plastic bottles as an alternative sustainable building material, Energy for Sustainable Development, 2015;24:79-85.

4 Mokhtar, M., Sahat, S., Hamid, B., Kaamin, M., Kesot, M.J., Law, C.W., Loo, Y.X., Ng, P.L. \& Sim, V.J.L. Application of plastic bottle as a wall structure for green house, ARPN Journal of Engineering and Applied Sciences, 2015;1-5.

5 Morel, J.C., Mesbah, A., Oggero, M. \& Walker, P. Building houses with local materials: means to drastically reduce the environmental impact of construction, Building and Environment, 2001;36:10:1119-1126.

6 Muyen, Z., Barna, T. \& Hoque, M. Strength properties of plastic bottle bricks and their suitability as construction materials in Bangladesh, Progressive Agriculture, 2016;27:3:362-368.

7 Oyinlola, M., Whitehead, T., Abuzeinab, A., Adelfila, A., Akinola, Y., Anafi, F., Farukh, F., Jegede, O., Kandan, K., Kim, B. \& Mosugu, E. Bottle House: A case study of transdisciplinary research for tackling global challenges, Habitat International, 2018;79:18-29.

8 Oyinlola, M. \& Whitehead, T., Recycling of plastics for low cost construction, Reference Module in Materials Science and Materials Engineering, Elsevier, 2019:16.

9 Oyeniyi, B.A. Waste management in contemporary Nigeria: the Abuja example, International Journal of Politics and Good Governance, 2011:2(2.2):1-18.

10 Patel, P.A., Shah, A. \& Patel, H. Waste Plastic Bottles Offering Innovative Building Materials with Sustainable Application, International Journal of Innovative and Emerging Research in Engineering, 2016;3:3:38-45.

11 Rawat, A.S. \& Kansal, R. PET bottles as sustainable building material a step towards green building construction, Journal of Civil Engineering and Environmental Technology, 2014;1:6:1-3.

12 Revathi, S., Rathinam, R.M., Kumar, T.R., Raman, M.S., Umanath, B. Reuse of Bottles for Wall Construction and Crafting, International Journal of Engineering Science, 2017;7:4:6693-6696.

13 Subramanian, N., Design of Steel Structures, Appendix C Properties of Soils, Oxford University Press, 2016.

14 Taaffe, J., O'Sullivan, S., Rahman, M.E. \& Pakrashi, V. Experimental characterisation of Polyethylene Terephthalate (PET) bottle Eco-bricks, Materials \& Design, 2014;60:50-56.

15 Lourenço, P.B. Experimental and numerical issues in the modeling of the mechanical behavior of masonry. In Proc. Structural analysis of historical constructions II, CIMNE, Barcelona. Edited by P. Roca et al., 1998:57-91 